\title{
PŘíSTROJE A POMU゚CKY Z KLEMENTINA VE SBÍRCE NÁRODNÍHO TECHNICKÉHO MUZEA
}

\author{
ANTONÍN ŠVEJDA

\section{SCIENTIFIC INSTRUMENTS AND AIDS FROM THE CLEMENTINUM IN THE COLLECTIONS OF THE NATIONAL TECHNICAL MUSEUM}

The National Technical Museum keeps a collection of important scientific instruments and aids which were originally used and kept in the Clementinum in Prague. In 1951, the museum had received 82 items, which were included in its collections on astronomy, land surveying, physics, and measurement of time. The most notable instruments from this set are part of permanent exhibitions on astronomy and measurement of time. Importance of this cultural heritage is further attested by the fact that in 2016, two instruments belonging to this acquisition, namely sextants which had belonged to Jost Bürgi and Erasmus Habermel, received the status of national cultural heritage.

Keywords: Clementinum - National Technical Museum - instruments: astronomical, land surveying, meteorological - demonstration aids - sextants

DOI: $10.14712 / 23365730.2018 .54$

\section{Úvod}

Akvizice přístrojů z Klementina je nejvýznamnějším přírůstkem do sbírek exaktních věd Národního technického muzea (NTM) od doby jeho založení v roce 1908. Díky této akvizici se upevnila pozice souboru astronomických prrístrojů jako jedné z nejlepších kolekcí historických aparátů v českých zemích. Přínos do dalších sbírek NTM je též velmi významný. Celkem se jedná o nárůst 82 předmětů rozličné povahy, které jsou uloženy v oddělení exaktních věd - v astronomii (40 ks), geodézii (13 ks) a fyzice (19 ks), ale také v oddělení strojírenství a měření času ve sbírce hodin $(10 \mathrm{ks})$. Soupis všech předmětů pocházejících z Klementina je uveden v tabulce (viz níže). Více než kvantita předaného fondu dominuje jeho kvalita, at' už se jedná o skupiny př́strojů nebo jednotlivé exempláře. Vždyt’ byl předán takový celek, jako je světově proslulá řada astrometrických zařizení pocházejících z doby od konce 16. století až do dvacátých let 19. století, kterým se právem pyšní naše muzeum. Jedinečný je i soubor fyzikálních aparátů používaných při proslulých měřeních v meteorologické observatoři Klementina během 19. století. Kolekce demonstračních předmětů obsahuje některá unikátní zařízení, jako třeba uranoskop a přístroj se čtyřmi glóby, jinde se nevyskytující. Sbírka hodin představuje významné konstrukce astronomických sekundérů a podlahových hodin použitých při astronomické observaci. $\mathrm{K}$ jedinečným předmětům patří 
rovněž délkový etalon vídeňského sáhu, sluneční hodiny na polokouli, námořní astroláb, obraz astronoma Johanna Kleina a další.

Po únorovém převratu v roce 1948 došlo u nás na konci čtyřicátých a počátkem padesátých let 20. století k velkým celospolečenským změnám. Ty se dotkly také oblasti kultury, vědy a techniky, a tedy i muzejních fondů včetně sbírek vědeckých přístrojů. V roce 1951 byl předán popisovaný soubor ze Státní hvězdárny v Klementinu do NTM. Tento přesun byl nesporně pozitivní jak z pohledu muzea, tak i z hlediska vlastního zachování vědeckých př́istrojů. Na jedné straně vedl k trvalému zabezpečení vlastních unikátů a na straně druhé ke zvýšení prestiže muzejních sbírek. Část předaných zařízení byla vystavena v nově vzniklé expozici astronomie v roce 1960. V současné stálé astronomické výstavě NTM je prezentováno dvacet čtyři prŕístrojů a demonstračních pomůcek, v expozici měření času je instalováno pět kusů hodin a hodinových strojů. Zbývající předměty jsou uloženy v depozitářích muzea a slouží k dokumentaci historie vědy a techniky, ke studiu badatelů a čas od času k prezentaci na př́ležitostných výstavách. Některé z nich byly představeny na výstavě Jezuité a Klementinum, konané v Galerii Klementinum v roce 2006. Další předměty byly v uplynulých desetiletích součástí výstav doma i v zahraničí. Na konci devadesátých let 20. století bylo NTM požádáno o souhlas se zhotovením kopií dvou světoznámých sextantů Bürgiho a Habermela pro Národní knihovnu. NTM této žádosti samozřejmě vyhovělo. Při př́ležitosti projektu Evropské město kultury Praha 2000 byla zpř́stupněna astronomická věž a barokní knihovní sál pro veřejnost. Kopie sextantů jsou trvale vystaveny v předsálí barokního sálu jako součást prohlídkové trasy Klementina.

\section{Astrometrické přístroje}

V 16. století se rozvinulo systematické pozorování nebe. Zásluhu na zdokonalení metod a pomůcek má Tycho Brahe, který nechal konstruovat př́stroje ${ }^{33}$ pro své observatoře na dánském ostrově Hven. Jeho instrumenty s přesnými průhledítky a precizně dělenými kruhy umožnily odečítání úhlů na jednotlivé úhlové minuty. Jednalo se především o kvadranty a sextanty, nejpřesnějším přístrojem pak byl kvadrant pevně zabudovaný na zdi orientované v rovině poledníku. Přesná Tychonova pozorování propočetl Johannes Kepler a zhodnotil je formulací zákonů pohybu planet. Klasická astrometrická pozorování vyvrcholila prací Johanna Hevelia na observatoři v Gdaňsku v 2. polovině 17. století. Pro astrometrická měření Hevelius používal k měření tradiční sektory (sextanty a kvadranty) a k pozorování objektů na nebi též dalekohled. Astrometrické př́istroje dále zdokonalil Jean Picard, který vybavil roku 1667 kvadrant dalekohledem místo mechanických zaměřovačů. Poprvé v historii byl spojen měřicí přístroj s dalekohledem do jednoho celku. Do dalšího vývoje astrometrie zasáhl William Gascoigne objevem mikrometru, který umožnil rozdělení úhlové minuty na vteřiny. V 18. a 19. století došlo v astrometrii k přelomovým objevům: aberace hvězd, ${ }^{34}$ zjištění vlastního pohybu hvězd a změření hvězdné paralaxy, které umožnilo spočítat vzdálenost hvězd. Později se astrometrie zaměřila na využití fotografie, díky níž bylo možné (dlouhou expozicí) zachytit málo viditelné objekty nebe. Zajímavostí je, že

33 Tycho BrAHE (1546-1601) popsal své př́stroje v knize Astronomiae instauratae mechanica, Wandsbeck1598.

34 Odchylka polohy hvězdy způsobená skládáním rychlostí světla a pohybu pozorovatele. 
Tabulka 1. Soupis prístrojů

\begin{tabular}{|c|c|c|c|c|c|}
\hline I. č. & Název & Skupina & Výrobce/autor & Datace & Poznámka \\
\hline 8126 & $\begin{array}{l}\text { Stroj věžních } \\
\text { hodin }\end{array}$ & Hodiny & $\begin{array}{l}\text { Sebastian Londensperger, } \\
\text { Praha }\end{array}$ & 1736 & $\begin{array}{l}\text { stroj věžních hodin } \\
\text { z věže Klementina }\end{array}$ \\
\hline 17115 & Anemograf & Fyzika & Patrick Adie, London & $1860-1880$ & \\
\hline 17116 & Anemograf & Fyzika & nesignováno & $1860-1880$ & \\
\hline 17117 & Altazimut & Astronomie & Edward Troughton, London & kolem 1800 & \\
\hline 17118 & Barograf & Fyzika & $\begin{array}{l}\text { Karel Kreil, hodiny F. } \\
\text { Dressler, Praha }\end{array}$ & 1844 & \\
\hline 17119 & Termograf & Fyzika & $\begin{array}{l}\text { Karel Kreil, hodiny F. } \\
\text { Dressler, Praha }\end{array}$ & 1860 & \\
\hline 17120 & Srážkoměr & Fyzika & nesignováno & 2. pol. 19. stol. & \\
\hline 17121 & Anemograf & Fyzika & E. Kraft \& Sohn, Wien & $1865-1880$ & \\
\hline 17122 & $\begin{array}{l}\text { Nivelační } \\
\text { rektifikační } \\
\text { přístroj }\end{array}$ & Geodézie & $\begin{array}{l}\text { Georg Friedrich Brander, } \\
\text { Augsburg }\end{array}$ & $1750-1783$ & \\
\hline 17123 & Barometr & Fyzika & $\begin{array}{l}\text { J. G. Greiner \& Geissler, } \\
\text { Berlin }\end{array}$ & $1870-1880$ & \\
\hline 17124 & Barometr & Fyzika & nesignováno & 2. pol. 19. stol. & \\
\hline 17125 & Barometr & Fyzika & nesignováno & 2. pol. 19. stol. & \\
\hline 17126 & Barometr & Fyzika & $\begin{array}{l}\text { signatury: Societas } \\
\text { Meteorologica Palatina, } \\
\text { Carolus Theodor Elector } \\
\text { Mussagetes Palatinus } 1780\end{array}$ & 1780 & $\begin{array}{l}\text { Societas Meteorologica } \\
\text { Palatina, Mannheim }\end{array}$ \\
\hline 17127 & Barometr & Fyzika & nesignováno & 2. pol. 19. stol. & \\
\hline 17128 & Barometr & Fyzika & nesignováno & 2. pol. 19. stol. & \\
\hline 17129 & Barometr & Fyzika & Carlo Grindel, Milano & 1. pol. 19. stol. & \\
\hline 17130 & Barometr & Fyzika & $\begin{array}{l}\text { signováno „Profesor } \\
\text { Hallaschka“ }\end{array}$ & $1814-1832$ & $\begin{array}{l}\text { František Ignác Kassián } \\
\text { Halaška - majitel }\end{array}$ \\
\hline 17131 & Barometr & Fyzika & L. J. Kappeller, Wien & pol. 19. stol. & \\
\hline 17132 & Barometr & Fyzika & nesignováno & 2. pol. 19. stol. & \\
\hline 17133 & Kvadrant & Astronomie & $\begin{array}{l}\text { signováno „... Franciscus } \\
\text { Kolowrat Nowohradský } \\
\text { Uraniae Prag donavit } \\
1790 \ldots \text {..." } \\
\end{array}$ & $1780-1790$ & $\begin{array}{l}\text { Franciscus Kolowrat } \\
\text { Nowohradský - donátor }\end{array}$ \\
\hline 17134 & $\begin{array}{l}\text { Obraz Johannes } \\
\text { Klein }\end{array}$ & Astronomie & nesignováno & $1751-1762$ & \\
\hline 17135 & Kvadrant & Astronomie & $\begin{array}{l}\text { Johannes Klein, Praha } \\
\text { Klementinum }\end{array}$ & 1762 & \\
\hline 17136 & Stativ dalekohledu & Astronomie & nesignováno & $1870-1890$ & azimutální montáž \\
\hline 17137 & $\begin{array}{l}\text { Magnetické } \\
\text { př́stroje }\end{array}$ & Fyzika & nesignováno & $1890-1920$ & \\
\hline 17138 & $\begin{array}{l}\text { Astronomický } \\
\text { teodolit (pasážník) }\end{array}$ & Astronomie & $\begin{array}{l}\text { Reichenbach \& Ertel, } \\
\text { Mnichov }\end{array}$ & $1820-1840$ & \\
\hline 17139 & Teodolit & Geodézie & $\begin{array}{l}\text { Reichenbach, Utzschneider } \\
\text { \& Liebherr, Mnichov }\end{array}$ & 1816-1818 & \\
\hline
\end{tabular}




\begin{tabular}{|c|c|c|c|c|c|}
\hline 17140 & Glóbus zemský & Geodézie & $\begin{array}{l}\text { Ludwig Julius Heymann, } \\
\text { Berlin }\end{array}$ & $1880-1890$ & \\
\hline 17141 & Glóbus zemský & Geodézie & Paul Oestergaard, Berlin & kolem 1912 & \\
\hline 17142 & Armilární sféra & Astronomie & Josef Jüttner, Praha & 1828 & \\
\hline 17143 & Telurium & Astronomie & Jan Felkl, Praha & kolem 1870 & \\
\hline 17144 & $\begin{array}{l}\text { Model dráhy } \\
\text { planet }\end{array}$ & Astronomie & nesignováno & kolem 1900 & \\
\hline 17145 & \begin{tabular}{|l}
$\begin{array}{l}\text { Model dráhy } \\
\text { planet }\end{array}$ \\
\end{tabular} & Astronomie & nesignováno & kolem 1900 & \\
\hline 17146 & Telurium & Astronomie & nesignováno & 2. pol. 19. stol. & \\
\hline 17147 & \begin{tabular}{|l} 
Permanentní \\
magnet
\end{tabular} & Fyzika & $\begin{array}{l}\text { Georg Friedrich Brander, } \\
\text { Augsburg }\end{array}$ & $1750-1783$ & \\
\hline 17148 & Planetárium & Astronomie & nesignováno & 16. stol. & \\
\hline $17149 / 1$ & Glóbus zemský & Geodézie & Jan Felkl \& Sohn, Praha & $1852-1870$ & \\
\hline $17149 / 2$ & Glóbus zemský & Geodézie & Jan Felkl \& Sohn, Roztoky & $1875-1880$ & \\
\hline 17150 & Stínítko na lampu & Geodézie & \begin{tabular}{|l} 
Stelzig, Kittel \& Co, \\
Kamenický Šenov
\end{tabular} & kolem 1882 & \begin{tabular}{|l|} 
stínítko s obrazem \\
zemského glóbu
\end{tabular} \\
\hline 17151 & $\begin{array}{l}\text { Sluneční hodiny } \\
\text { analematické }\end{array}$ & Astronomie & $\begin{array}{l}\text { P. Aurelius Augustino, } \\
\text { Wien }\end{array}$ & pol. 18. stol. & \\
\hline 17152 & Heliometr & Astronomie & $\begin{array}{l}\text { Georg Friedrich Brander, } \\
\text { Augsburg }\end{array}$ & $1750-1783$ & \\
\hline 17153 & Glóbus Měsíce & Astronomie & Camille Flammarion, Paris & 1895 & $\begin{array}{l}\text { vydavatel E. Bertaux, } \\
\text { Paris }\end{array}$ \\
\hline 17154 & Glóbus Marsu & Astronomie & Camille Flammarion, Paris & 1884 & $\begin{array}{l}\text { vydavatel E. Bertaux, } \\
\text { Paris }\end{array}$ \\
\hline 17156 & Glóbus zemský & Geodézie & $\begin{array}{l}\text { Carl Ferdinand Weiland, } \\
\text { Weimar }\end{array}$ & 1843 & \\
\hline 17157 & Kyvadlo roštové & Hodiny & nesignováno & 1. pol. 19. stol. & \\
\hline 17158 & \begin{tabular}{|l|}
$\begin{array}{l}\text { Kyvadlo roštové } \\
\text { kompenzační }\end{array}$ \\
\end{tabular} & Hodiny & nesignováno & 1. pol. 19. stol. & \\
\hline 17160 & Armilární sféra & Astronomie & nesignováno & 2. pol. 18. stol. & \\
\hline 17165 & Astrochronometr & Astronomie & L. Deichmann, Kassel & kolem 1888 & \\
\hline 17166 & $\begin{array}{l}\text { Gnomon } \\
\text { univerzální }\end{array}$ & Astronomie & Václav Grund, Praha & $1860-1880$ & \\
\hline 17168 & Uranoskop & Astronomie & Václav Grund, Praha & 1860 & \begin{tabular}{|l} 
autor glóbu Josef \\
Georg Böhm \\
\end{tabular} \\
\hline 17169 & $\begin{array}{l}\text { Demonstrační } \\
\text { prístroj se čtyřmi } \\
\text { glóby }\end{array}$ & Astronomie & Jan Felkl, Praha & $1852-1870$ & $\begin{array}{l}\text { autor glóbu Otto } \\
\text { Delitsch, Lipsko }\end{array}$ \\
\hline 17171 & Glóbus zemský & Geodézie & Jan Felkl, Roztoky & $1876-1900$ & \begin{tabular}{|l|} 
autor glóbu Otto \\
Delitsch, Lipsko \\
\end{tabular} \\
\hline 17172 & $\begin{array}{l}\text { Dalekohled } \\
\text { hvězdářský }\end{array}$ & Astronomie & Petr Lohner, Praha & 1826 & paralaktická montáž \\
\hline 17173 & Dalekohled & Astronomie & nesignováno & & paralaktická montáž \\
\hline 17174 & \begin{tabular}{|l}
$\begin{array}{l}\text { Astronomický } \\
\text { sekundér }\end{array}$ \\
\end{tabular} & Hodiny & Josef Božek, Praha & $1800-1825$ & \\
\hline 17175 & Stativ dalekohledu & Astronomie & nesignováno & 2. pol. 19. stol. & paralaktická montáž \\
\hline
\end{tabular}




\begin{tabular}{|c|c|c|c|c|c|}
\hline 17176 & $\begin{array}{l}\text { Dalekohled } \\
\text { terestrický }\end{array}$ & Astronomie & Voigtländer \& Sohn, Wien & kolem 1800 & \\
\hline 17177 & Glóbus zemský & Geodézie & Josef Jüttner, Wien & 1839 & \\
\hline 17178 & Glóbus zemský & Geodézie & $\begin{array}{l}\text { Josef Jüttner, Franz } \\
\text { Lettany, Praha }\end{array}$ & 1822 & \\
\hline 17180 & Pasážník & Astronomie & Andreas Jaworski, Wien & $1821-1829$ & \\
\hline 17181 & Pasážník & Astronomie & Andreas Jaworski, Wien & $1821-1829$ & torzo přístroje \\
\hline 17182 & Astroláb námořní & Astronomie & $\begin{array}{l}\text { Petrus de Heubder, } \\
\text { Antwerpen }\end{array}$ & $\begin{array}{l}\text { počátek } 17 . \\
\text { stol. }\end{array}$ & \\
\hline 17183 & $\begin{array}{l}\text { Sluneční hodiny } \\
\text { rovníkové }\end{array}$ & Astronomie & $\begin{array}{l}\text { Johann Georg Vogler, } \\
\text { Augsburg }\end{array}$ & kolem 1750 & \\
\hline 17184 & $\begin{array}{l}\text { Kapesní } \\
\text { chronometr }\end{array}$ & Hodiny & nesignováno & $1780-1820$ & $\begin{array}{l}\text { pravděpodobně Paul } \\
\text { Philipp Barraud, London }\end{array}$ \\
\hline 17185 & $\begin{array}{l}\text { Sluneční hodiny } \\
\text { rovníkové }\end{array}$ & Astronomie & nesignováno & kolem 1850 & \\
\hline 17186 & Magnetovec & Fyzika & nesignováno & 19. stol. & \\
\hline 17187 & $\begin{array}{l}\text { Sluneční hodiny } \\
\text { vodorovné }\end{array}$ & Astronomie & nesignováno & 18. stol. & \\
\hline 17188 & Sluneční hodiny & Astronomie & $\begin{array}{l}\text { Matthaeus Heintzius, } \\
\text { Leipzig }\end{array}$ & 1. pol. 17. stol. & \\
\hline 17189 & $\begin{array}{l}\text { Sluneční hodiny } \\
\text { tvaru skafé }\end{array}$ & Astronomie & Marcus Purman, Mnichov & 1588 & \\
\hline 17190 & $\begin{array}{l}\text { Plaketa Camille } \\
\text { Flammarion }\end{array}$ & Astronomie & Alexander Zeitlin & 1911 & $\begin{array}{l}\text { plaketa na počest } \\
\text { C. Flammariona }\end{array}$ \\
\hline 17191 & $\begin{array}{l}\text { Medaile Museo } \\
\text { Francisco } \\
\text { Carolinum }\end{array}$ & Astronomie & & 1883 & \\
\hline 17192 & $\begin{array}{l}\text { Ložisko pro } \\
\text { pasážník }\end{array}$ & Astronomie & nesignováno & 19. stol. & \\
\hline 17193 & $\begin{array}{l}\text { Stojan k } \\
\text { dalekohledu }\end{array}$ & Astronomie & nesignováno & $1890-1920$ & \\
\hline 17194 & $\begin{array}{l}\text { Trigonometrické } \\
\text { měřítko }\end{array}$ & Geodézie & Eduard Apfelbeck, Wien & kolem 1900 & \\
\hline 17195 & Sextant & Astronomie & Jost Bürgi, Praha & 1600 & \\
\hline 17196 & $\begin{array}{l}\text { Etalon vídeňského } \\
\text { sáhu }\end{array}$ & Geodézie & nesignováno & 1756 & \begin{tabular}{|l|} 
správce míry - \\
Josef Franz, S. J.
\end{tabular} \\
\hline 18180 & $\begin{array}{l}\text { Hvězdáŕský } \\
\text { sekundér }\end{array}$ & Hodiny & Johann Philip Vötter, Wien & $1755-1757$ & stroj číslován Nr. 4 \\
\hline 18181 & $\begin{array}{l}\text { Stojací podlahové } \\
\text { hodiny }\end{array}$ & Hodiny & nesignovánoo & 2. pol. 18. stol. & \\
\hline 18182 & $\begin{array}{l}\text { Bicí hodiny s } \\
\text { kalendářem }\end{array}$ & Hodiny & $\begin{array}{l}\text { Vitalis Zacharis Sutter, } \\
\text { Praha }\end{array}$ & 2. pol. 18. stol. & \\
\hline 18183 & $\begin{array}{l}\text { Stojací podlahové } \\
\text { hodiny }\end{array}$ & Hodiny & Josef Božek, Praha & poč. 19. stol. & \\
\hline 18184 & $\begin{array}{l}\text { Hvězdáŕský } \\
\text { sekundér }\end{array}$ & Hodiny & Johann Philip Vötter, Wien & $1750-1755$ & stroj číslován Nr. 3 \\
\hline 24551 & Sextant & Astronomie & Erasmus Habermel, Praha & 1600 & \\
\hline 24771 & Kvadrant & Astronomie & $\begin{array}{l}\text { Johann Georg Fellwöck, } \\
\text { Würzburg }\end{array}$ & 1766 & \\
\hline
\end{tabular}



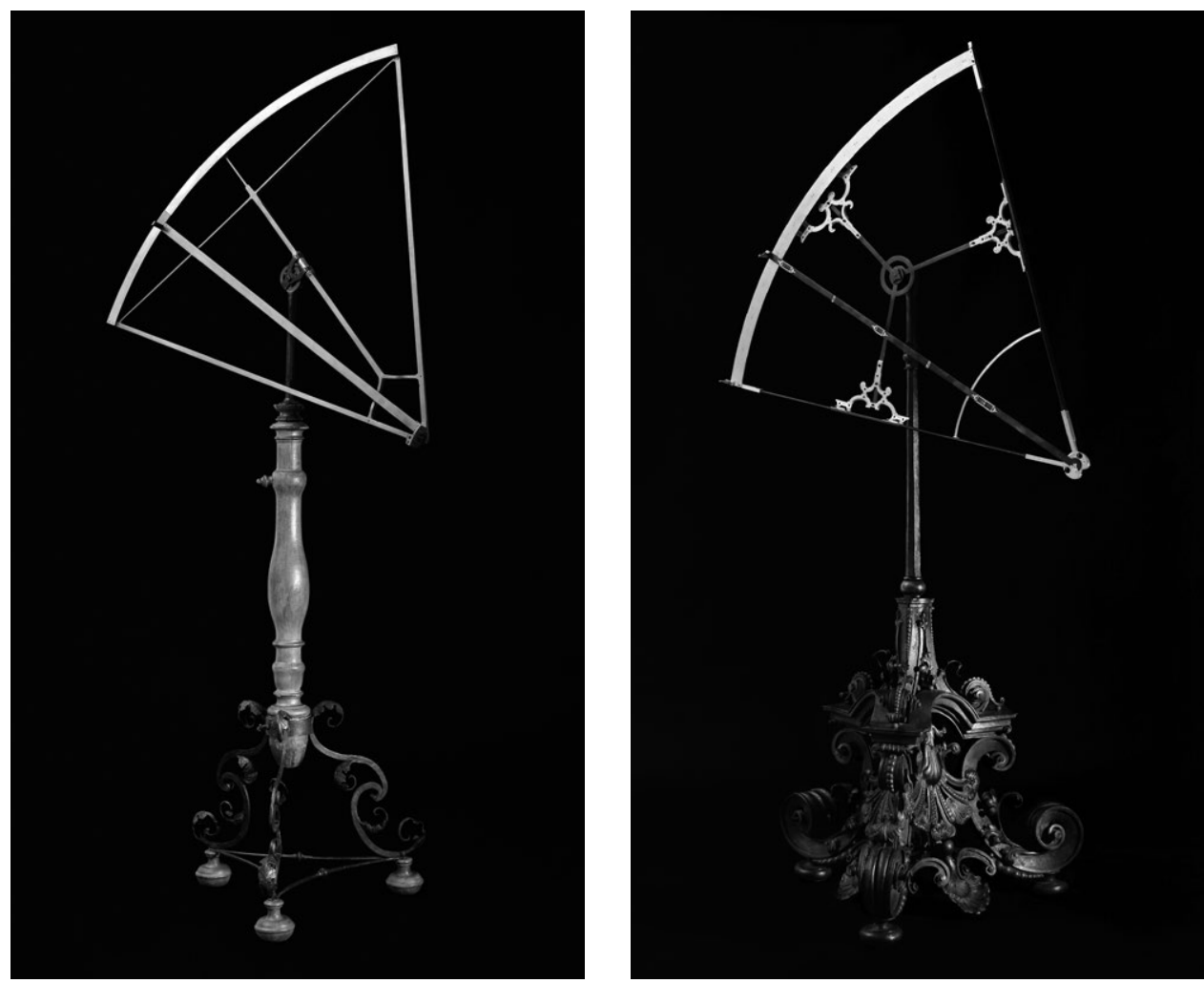

Obr. 1a,b Sextanty rudolfínské doby z dílen Josta Bürgiho a Erasma Habermela (foto Kateřina Uksová)

fotografie v astronomii je spojená i s Klementinem. Ladislav Weinek ${ }^{35}$ pořídil roku 1885 první fotografický snímek letícího meteoru na světě. Později vydal i první fotografický atlas Měsíce, a to na základě fotografických snímků zaslaných z Kalifornie a Paříže.

Nejvýznamnější akvizicí z Klementina je řada astrometrických přístrojů, která se stala základem expozice astronomie NTM. Z doby působení Tychona Brahe a Johanna Keplera v Čechách na přelomu 16. a 17. století se dochovaly dva pražské sextanty, které patři mezi stěžejní předměty svého druhu ve světových sbírkách. Tato zařízení sloužila k astronomickému měření úhlových vzdáleností dvou těles na obloze. Jsou vybaveny mechanickými zaměřovači, protože vznikly v době před objevením dalekohledu. Kvalita pozorování byla tedy závislá na zraku a schopnostech pozorovatele. Bürgiho sextant je přesný a jednoduchý přístroj, se kterým pravděpodobně měřil Johannes Kepler. ${ }^{36}$ Sextant zhotovil Jost Bürgi, ${ }^{37}$

35 Ladislav Weinek (1848-1913), ředitel klementinské hvězdárny a profesor astronomie na pražské univerzitě.

36 Matematik Jan Kepler (1571-1630) s ním pozoroval planetu Mars (dvě opozice v letech 1602 a 1604) z důvodu velké výstřednosti dráhy. Ta se stala klíčem k určení elipsy jako tvaru dráhy planety. Kepler popsal své výzkumy planetárních drah do tří zákonů pohybu planet.

37 Jost Bürgi (1552-1632), konstruktér prŕístrojů, astronom a matematik. Působil na pražském dvoře císařů Rudolfa II. a Matyáše jako dvorní hodinář. Sextantem bylo možné měřit s přesností na jednotlivé úhlové minuty. 


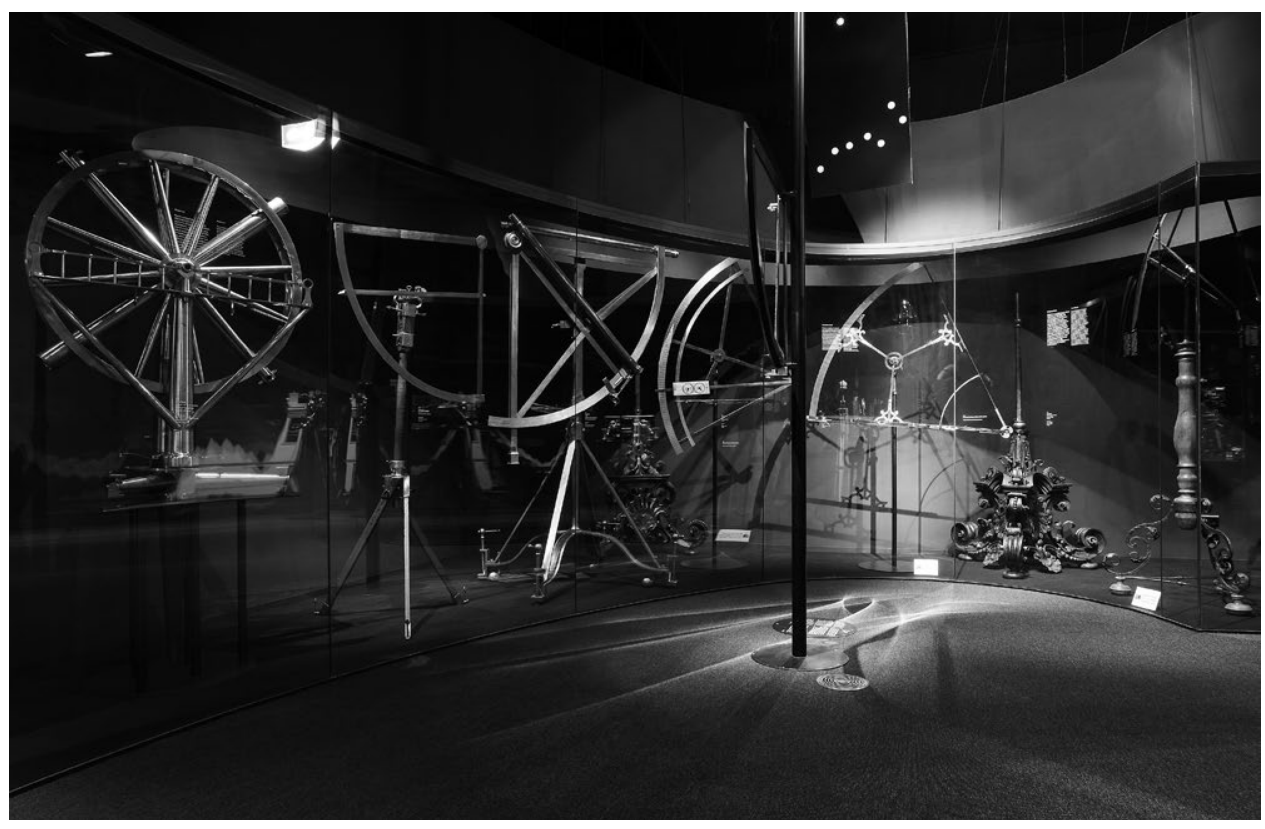

Obr. 2 Pohled do expozice astronomie NTM na astrometrické přístroje (zprava): sextant (inv. č. 17195) J. Bürgi, sextant (inv. č. 24551) E. Habermel, kvadrant (inv. č. 17133) nesignován, kvadrant (inv. č. 24771) J. G. Fellwöck, kvadrant (inv. č. 17135) J. Klein, altazimut (inv. č. 17117) E. Troughton (foto Patrik Sláma)

hodináŕ a Keplerův spolupracovník. Tělo sextantu je tvořeno koncovými rameny úhlu a dvěma vzpěrami. Sextant má k zacílení dvě důmyslná průhledítka, je možné s ním měřit úhlovou vzdálenost v libovolné rovině. Př́ístroj má limbus poloměru $1122 \mathrm{~mm}$, odečítací pomůcky umožňují určení úhlu až na 1 obloukovou minutu $\left(1^{\prime}\right) .{ }^{38}$ Pro pozorování pod širým nebem byl sextant upevněn do kamenného bloku, jinak byl uložen v lehkém kovaném renesančním stativu s dřevěnými částmi.

Druhý sextant vytvořil Erasmus Habermel. ${ }^{39}$ Na rozdíl od Bürgiho výtvoru je jeho sextant zdobný a není známo, pro koho byl vyroben. Tělo sextantu tvoří limbus, dvě koncová ramena a tři vzpěry vedoucí do těžiště prrístroje. Limbus poloměru $1317 \mathrm{~mm}$ je dělen na $60^{\circ}$, díky dělení alhidády je možné odečíst úhel opět s přesností na 1'. Zajímavostí je uložení měřicího aparátu v železném kovaném stativu, který je barokní prací z poloviny 18. století. Stativ sloužil ke kabinetnímu uložení sextantu. Je zřejmé, že oba př́ístroje vznikly pod př́mým vlivem činnosti slavných astronomů a matematiků na rudolfínském dvoře v Praze

38 O měření tímto sextantem a o možnosti vyloučení rozlišovací schopnosti lidského oka viz též Zdislav ŠímA, Prague Sextants of Tycho Brahe, Annals of Science 50/5, 1993, s. 445-453. Dokazuje, že bylo možné použít oči jen jako čidla, zda světlo prochází či nikoli.

39 Erasmus Habermel (?-1606) byl dvorní mechanik císaře Rudolfa II. Specializoval se na menší pomůcky, jako jsou přenosné sluneční hodiny, rýsovací a měřicí pomůcky. Sextant je jeho jediný velký přístroj. 


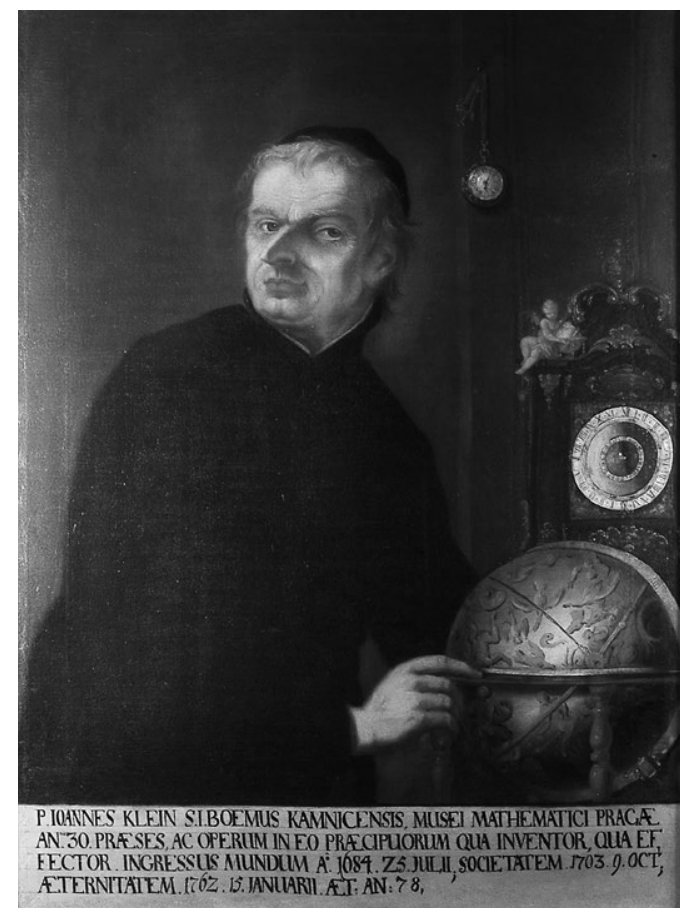

Obr. 3 Johannes Klein (inv. č. 17134), olejomalba, nesignováno. Klein je zachycen v černém jezuitském obleku s hvězdným glóbem, vlastními astronomickými hodinami a Emeryho chronometrem na zdi (foto Patrik Sláma)

(Tadeáš Hájek z Hájku, Tycho Brahe a Johannes Kepler). Oba sextanty se pak neznámými cestami dostaly do Matematického muzea $v$ Klementinu a později do NTM.

Řada dále pokračuje dvěma kvadranty z 18. století. První z nich sestrojil Johannes Klein ${ }^{40} \mathrm{v}$ druhé polovině 18 . století. Kvadrant je vybaven alhidádou k odečíání úhlů (stupně, minuty a vteřiny). Stupnice však nejsou dohotoveny a navíc př́stroj nemá pomůcky k zacílení (vizíry nebo dalekohled). Z toho vyplývá, že kvadrant nebyl nikdy dokončen. Zřejmě si Klein uvědomil, že přesnost úhlových vteřin je touto mechanikou nedosažitelná. Způsob konstrukce kvadrantu, tvar limbu a vzpěry jdoucí do těžiště ukazují na to, že konstruktérovi sloužil za vzor Habermelův sextant. Navíc jsou oba stativy podobné. Druhý kvadrant je jednoduché konstrukce, je železný s jednou vzpěrou. S jedním ramenem sektoru je spojena trubka, která pravděpodobně obsahovala optiku a fungovala jako dalekohled. Př́istroj zřejmě daroval hrabě František Kolowrat Nowohradský ${ }^{11}$ hvězdárně v Klementinu v době ředitele Antonína Strnada.

40 J. Klein (1684-1762), člen jezuitského řádu, český astronom a mechanik. Kromě tohoto kvadrantu sestrojil další dva zední kvadranty s dalekohledy pro meridiánovou síň astronomické věže v Klementinu a čtvery astronomické hodiny (troje jsou uloženy v Klementinu, jedny v Matematicko-fyzikálním salonu v Drážd’anech).

41 Dedikace na př́stroji: Quem Illustrissimus ac Excellentiss. DDSRI Comes Franciscus Kolowrat Nowohradsky Uraniae Prag donavit 1790 Cui hora ut felix tempus in omne fluat precatur Ant. Strnadt Astro:pra. 


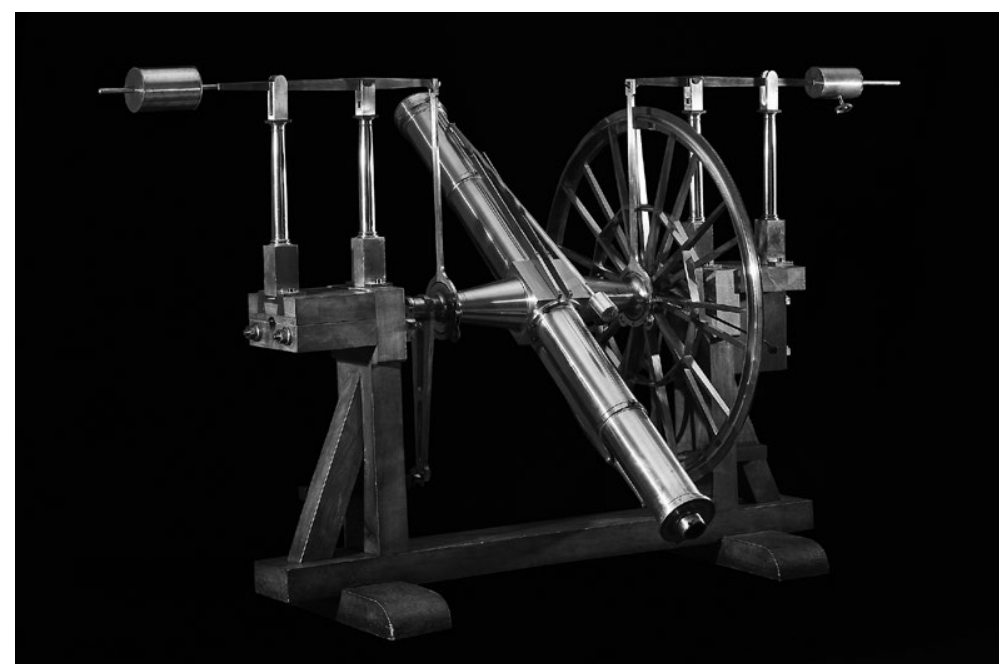

Obr. 4 Pasážník (inv. č. 17180), Andreas Jaworski, Vídeň, dvacátá léta 19. století, 37palcový (940 mm) vertikální kruh (foto Kateřina Uksová)

Pozoruhodným př́ístrojem je kvadrant pocházející z dílny J. G. Fellwöcka ${ }^{42}$ ve Würzburgu. Jedná se o instrument, který převyšuje předchozí a dává měření novou dimenzi. Má pevnou a jednotnou konstrukci měřicího př́stroje se stojanem. K měření se postaví na místo na hvězdárně a urovná do vodorovné polohy, což je nutné k měření obzorníkových souřadnic (výška, azimut). Kvadrant má přesnou stupnici poloměru 40 palců $(1027 \mathrm{~mm})$. Je opatřena mikrometrem od mechanika Jacques Caniveta $\mathrm{z}$ Paříže k měření svislých úhlů s přesností na jednotlivé vteřiny. Vodorovné úhly je možné měřit na stupnici poloměru $335 \mathrm{~mm}$. Navíc je kvadrant vybaven dvojicí čočkových dalekohledů (průměr $36 \mathrm{~mm}$, délka $1285 \mathrm{~mm}$ ) k zacílení, což ho předurčuje k přesným astrometrickým měřením. Na hlavním limbu kvadrantu je označení výrobce: „IOHANN GEORG FELLWECK MECHANICUS WIRCEBURGI FECIT 1766“.

Pokud astronom potřebuje měřit množství hvězdných pozic, musí být jeho dalekohled uložen na vhodném stojanu. Konstrukce montáže a robustnost stojanu v kombinaci se zařízením pro přesné odečítání úhlů jsou nezbytné. Zcela novou koncepci tak má altazimut E. Troughtona ${ }^{43} \mathrm{z}$ doby kolem roku 1800 . Jde o účelový př́stroj k měření obzorníkových (horizontálních) souřadnic. Pozice tělesa na nebeské sféře je určena nebeským horizontem a zenitem. ${ }^{44}$ Tento velký nepřenosný altazimut má 37,5palcový (955 mm) vertikální kruh a 14palcový (350 mm) horizontální kruh. Dalekohled je dvojitý a kř́žově uspořádaný. Altazimut má speciální zařízení k postavení do vodorovné polohy (rtutový horizont), úhly (svislý i vodorovný) se odečítají mikrometry v protilehlých polohách.

42 Johann Georg Fellwöck (1728-1810), hodinář a mechanik, konstruoval také dva zední kvadranty, astronomické kyvadlové hodiny a planetárium.

43 Edward Troughton (1756-1835) vyráběl v Londýně vědecké přístroje, astronomické, navigační a geodetické. Mezi jeho úspěchy patří vybavení observatoře Greenwich (1816) pasážníkem.

44 Souřadnice v tomto systému jsou azimut a výška (anglicky altitude), odtud pochází název př́stroje altazimut. 
Další pomůcka je pasážník (průchodní stroj), který se pohybuje pouze v rovině místního poledníku. Toto jednoúčelové vybavení je určeno $\mathrm{k}$ měření výšky nebeských těles $\mathrm{v}$ okamžiku jejich průchodu místním poledníkem a ve spojení s měřením času i jeho rektascenzí. Na hvězdárně má jedno stálé místo s přesně určeným poledníkem, které se nemění. Dřevěná konstrukce nese čočkový dalekohled s točnou osou, svislý kruh a vyvažovací zařízení. Př́istroj sestrojil Andreas Jaworski ${ }^{45}$ ve Vídeňském polytechnickém institutu.

Kromě řady astrometrických př́strojů se ve sbírce nachází astronomický teodolit (malý pasážník) s kruhy průměru $340 \mathrm{~mm}$ (vodorovný) a $321 \mathrm{~mm}$ (svislý). Oba úhly se odečíají pomocí mikroskopů na vernierech ve čtyřech polohách kruhů. Teodolit pochází ze známé mnichovské dílny Reichenbach \& Ertel.

\section{Sluneční hodiny}

Budova Klementina je bohatá na nástěnné venkovní sluneční hodiny. V matematickém muzeu se nacházela také sbírka přenosných slunečních hodin, především cestovních a kabinetních, jak byly standardně zastoupeny ve sbírkách historických přístrojů. Počet přenosných slunečních hodin běžně převyšoval hodiny na pevných stanovištích. Bylo to hlavně tím, že existovalo mnoho možností a typů přenosných slunečních hodin. Produkce slunečních hodin byla podpořena rozvojem deskriptivní geometrie, která byla pro konstrukci těchto časoměrných prístrojů nezbytnou. Růst výroby přenosných slunečních hodin začal $\mathrm{v}$ době renesance a pokračoval i v baroku, stejně tak se v 15.-18. století rozvíjela gnómonika (nauka o slunečních hodinách). Sluneční hodiny jsou založeny na principu, který využívá zdánlivého pohybu Slunce na obloze a měří čas podle stínu ukazatele, vrženého na stupnici.

Z Klementina se do NTM dostalo vedle běžných konstrukcí také několik pozoruhodných kousků. Mezi ně patř́i výjimečný typ hodin ve tvaru duté polokoule, tzv. skafé. V tomto př́stroji jsou vyneseny kromě slunečních i měsíční hodiny. Pokud jsou hodiny správně orientovány, mají univerzální použití na libovolném místě na Zemi. Předmět je krásně zdoben rytinami, jedná se o jemnou renesanční práci mechanika Markuse Purmanna, ${ }^{46}$ který se specializoval na sluneční hodiny ve tvaru poháru, křiže, kruhové, krabicové a diptychové hodiny. Př́stroj je signován „,1588 FECIT DE MONACHIA MARCVS PVRMAN HOROLOGIUM SOLIS ET LVNAE“.

Další renesanční prací jsou diptychové sluneční hodiny pocházející z Lipska a signované „Matthaeus Heintzius Fecit Lipsiae“. Jedná se o dvojité hodiny svislé a vodorovné, spojené do jednoho celku. K orientaci hodin sloužil kompas.

Pokud mají hodiny vodorovný nebo svislý číselník, jsou konstruovány pouze pro určitou zeměpisnou šířku. To je prípad barokních vodorovných hodin zdobených rytinami, které pocházejí z Vídně.

45 Andreas Jaworski působil ve špičkových dílnách Evropy (Reichenbach v Mnichově a Troughton v Londýně) a dosáhl vynikající pověsti. Jako vedoucí mechanik v „K. u. K. polyt. Institut in Wien“ se podílel na výrobě velkých astronomických př́strojů pro observatoře (pasážníky, astronomické teodolity, montáže dalekohledů).

46 Markus Purmann byl mnichovský výrobce mechanických a slunečních hodin a kompasů v letech 1588-1616. 

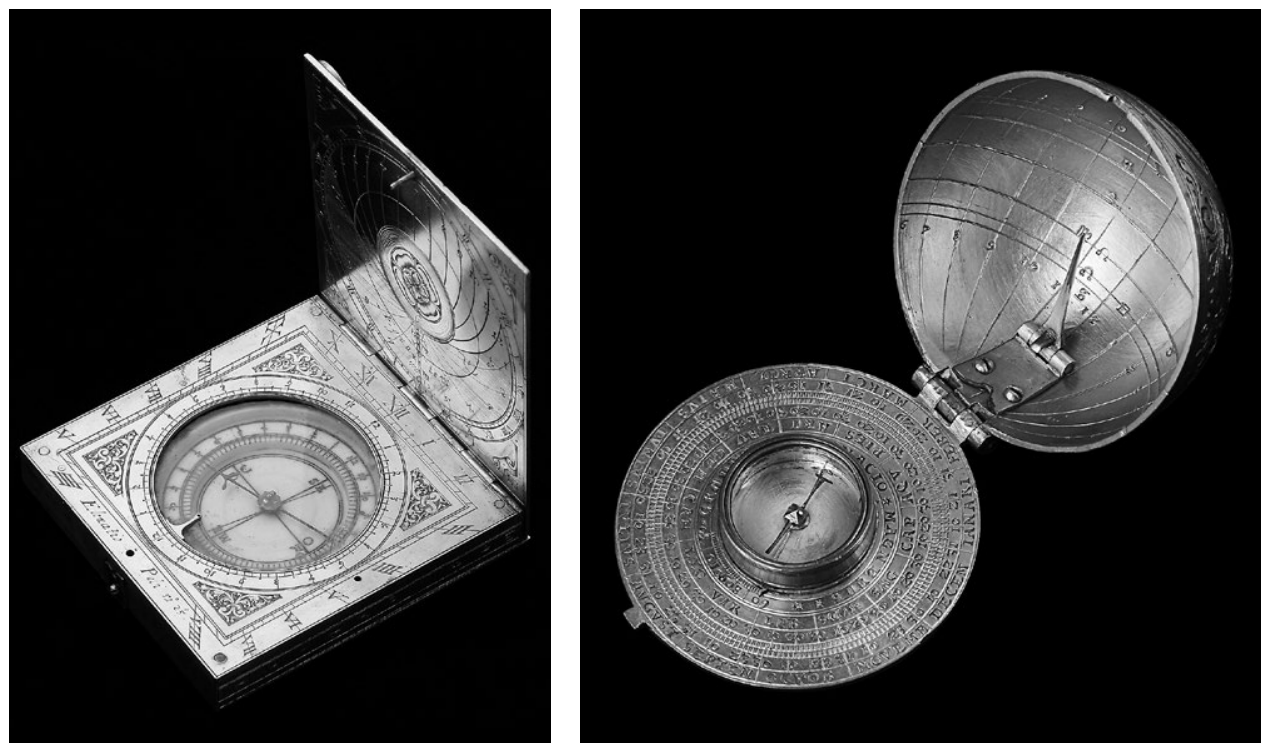

Obr. 5a Diptychové sluneční hodiny Obr. 5b Skafé (inv. č. 17189), Markus Purmann (inv. č. 17188), Matthaeus Heintzius Lipsko, první polovina 17. století, Kateřina Uksová) $69 \times 78 \times 74 \mathrm{~mm}$ (foto Kateřina Uksová)

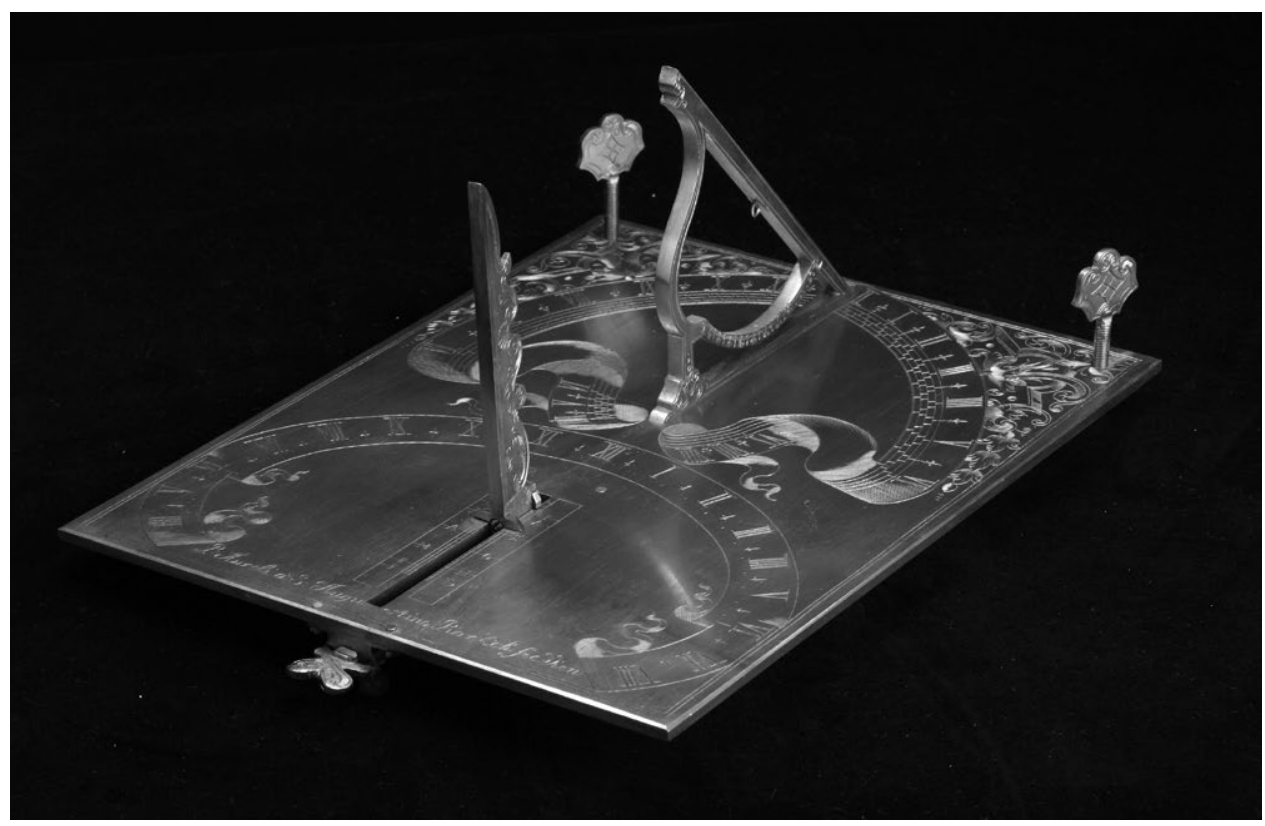

Obr. 5c Sluneční hodiny analematické (inv. č. 17151), P. Aurelius Vídeň, 18. století, deska $196 \times 255$ mm (foto Kateřina Uksová) 


\section{Dalekohledy}

Je zajímavé, že sbírka dalekohledů původem z Klementina je poměrně malá. Jde pouze o tři kusy a několik nekompletních stojanů s montáží. A přitom právě dalekohled se stal klíčovým pozorovacím přístrojem posledních čtyř staletí. Změnil naše vnímání světa a vesmíru kolem nás. Od základů proměnil představy o tom, jak vypadají objekty na obloze. Ale nejde jen o astronomické pozorování. Dalekohled má univerzální použití i v observaci na souši i na moři. Ve svých přístrojích ho používají zeměměřiči, je stěžejní pomůckou cestovatelů i námořníků a dalších pozorovatelů oblohy, přírody i zemského povrchu. Ve své podstatě se původně jednalo o jednoduchý nástroj se dvěma čočkami vloženými do trubice. V Nizozemí roku 1608 byla podána žádost o udělení patentu na vynález př́stroje ,k viděni vzdálených věcí, jako by byly pobližz". Vzhledem $\mathrm{k}$ tomu, že se jednalo o jednoduchou věc a žádosti byly postupně předloženy tři, nebyl nakonec patent ani udělen. Kromě dalekohledu, který obsahoval čočky, se později ještě objevil dalekohled se zrcadly, jež tvořila jeho objektiv. Dalekohled poté prodělal prudký rozvoj a ovládl pozorovací astronomii.

První z této skupiny sbírkových předmětů je astronomický čočkový dalekohled (refraktor) ${ }^{47} \mathrm{~s}$ paralaktickou (rovníkovou) montáží pocházející z 19 . století. $V$ dřevěném podstavci je uložena montáž dalekohledu složená ze dvou os, polární a deklinační. Osy jsou vybaveny dělenými kruhy se stupnicemi k měření úhlů. Refraktor je nekompletní, chybí mu optika. Tř́palcový tubus dalekohledu má z jedné strany nasazenu objímku objektivu a z druhé strany je vsazen okulárový tubus. Paralaktická montáž je pro pozorovatele výhodná, umožňuje

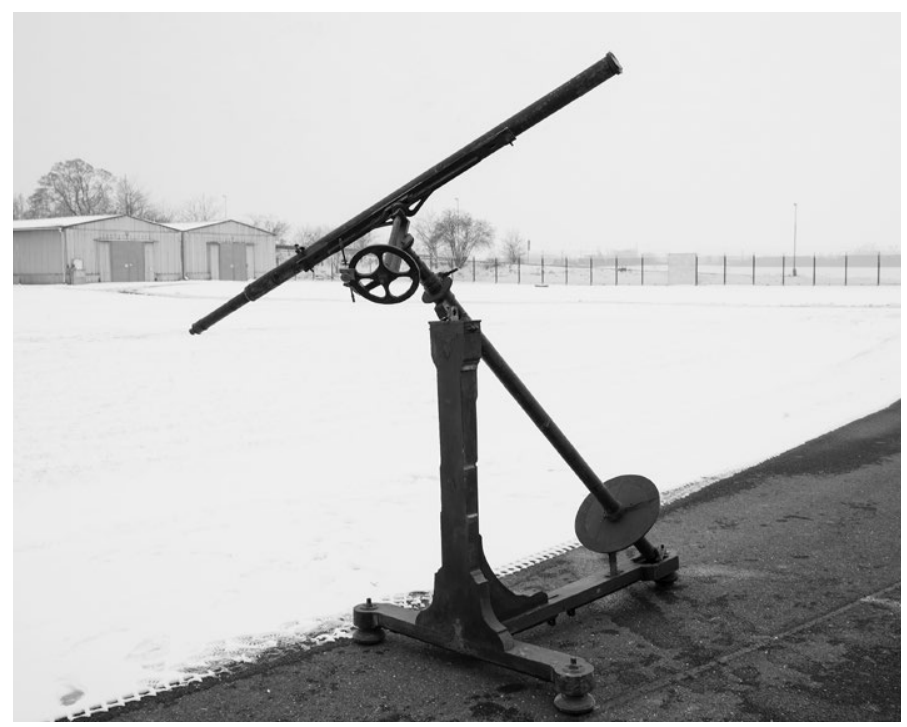

Obr. 6a Astronomický dalekohled (průměr 80, délka 1860 mm) s okulárem (průměr 70, délka $420 \mathrm{~mm}$ ), (inv. č. 17172) (foto Patrik Sláma)

47 Dle dř́ivějších záznamů v centrální evidenci exponátů NTM jde o dalekohled signovaný „Petr Lohner Praha $1826 “$. 


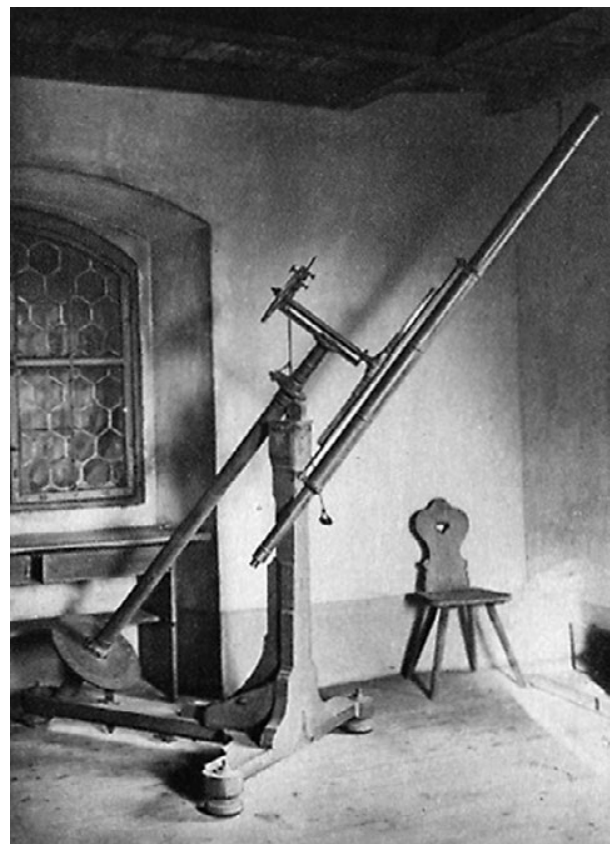

Obr. 6b Stejný dalekohled (inv. č. 17172) ve věži Státní hvězdárny v Praze na pohlednici Nakladatelství knihovny prrátel oblohy (po r. 1925)

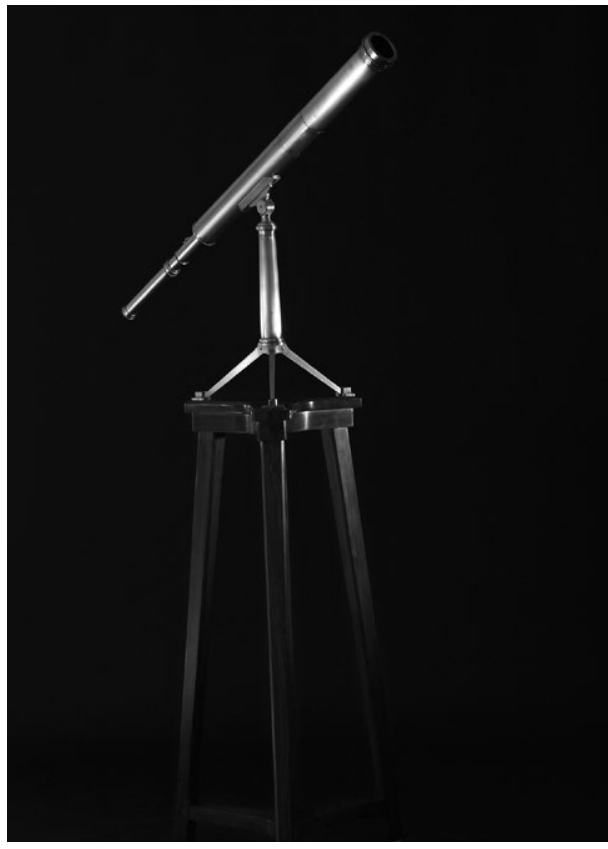

Obr. 7 Dalekohled (inv. č. 17176), J. Ch. Voigtländer, 3palcový (průměr $70 \mathrm{~mm}$ ) objektiv, stojan výšky $1100 \mathrm{~mm}$ (foto Kateřina Uksová)

nastavit dalekohled k dlouhodobému sledování jednoho objektu na obloze. K udržení pozorovaného objektu $\mathrm{v}$ zorném poli stačí pohybovat dalekohledem $\mathrm{v}$ jedné ose. U některých dalekohledů vykonává tento pohyb hodinový stroj.

Ve sbírce je i další dalekohled k pozemskému pozorování (terestrický). Dalekohled má jednodušší azimutální montáž se dvěma točnými osami, vodorovnou a svislou. Pokud by byl dalekohled vybaven úhloměrnými kruhy a kompasem, bylo by možno měřit dvě souřadnice (azimut a výšku) objektů na obloze. V tomto prŕpadě se však jedná o jednoduchý pozorovací dalekohled se svislým sloupkem a třínožkou. Je upevněn na dřevěném stativu, který si nechal zhotovit jeho uživatel. Na dalekohledu je signatura výrobce „VOIGTLAENDER \& Sohn in Wien“ ",8 pochází z doby přelomu 18. a 19. století. Dalekohled se skládá ze základního tubusu s objektivem a z tubusu s okulárovým výtahem. Okulár je terestrický, dalekohled dává př́ímý obraz.

Dalším předmětem, který bývá uživán jako příslušenství k dalekohledu, je heliometr. Slouží $\mathrm{k}$ měření malých úhlů $\left(\right.$ do $\left.1^{\circ}\right)$ na obloze, průměrů Slunce, Měsíce a planet, vzdálenosti složek dvojhvězd a určení paralax hvězd. Při nasazení heliometru na objektiv dalekohledu dochází k rozdělení obrazu na dvě části. Protilehlé body dvou obrazů v zorném poli

48 Firmu založil Johann Christoph Voigtländer (1732-1797) roku 1756. Nejprve brousil čočky, později vyráběl dalekohledy, mikroskopy, fotografické objektivy a kamery. 


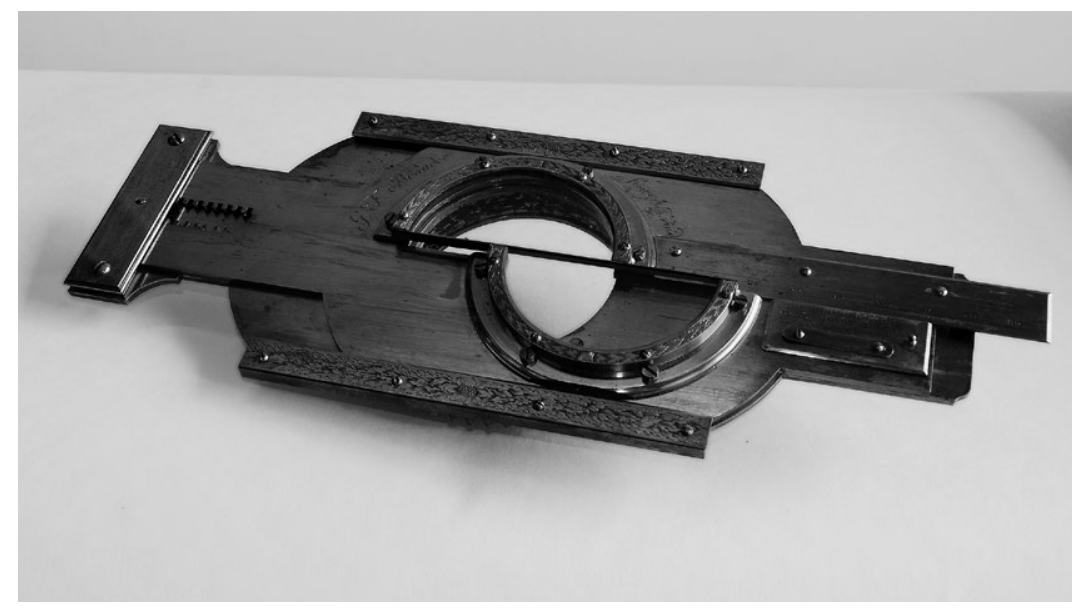

Obr. 8 Heliometr (inv. č. 17152), G. F. Brander, Augsburg, 1750-1783, délka 300 mm (foto Stanislav Dvořák)

dalekohledu se posunují tak, až splynou. Posunutí přesně odečtené na mikrometru je mírou úhlové vzdálenosti. Heliometr nese signaturu výrobce „G. F. Brander fecit Aug. Vind“.49

\section{Glóby a demonstrační pomůcky}

Velmi početným souborem v akvizici z Klementina do NTM jsou demonstrační předměty. Mezi nimi se nacházejí glóby, teluria, planetária, armilární sféry, uranoskopy, modely drah planet a další. Typickým předmětem této skupiny je glóbus jako učební pomůcka. Je obrazem Země, jiného tělesa (Měsíc, Merkur, Venuše, Mars, Jupiter, Saturn) nebo hvězdné oblohy. Hvězdný glóbus znázorňuje oblohu bez Slunce, Měsíce a planet při pohledu z vnějšku. Jsou na něm vyznačeny hvězdy a souhvězdí, u starších glóbů s figurální kresbou v podobě hrdinů a zvířat. Velmi populární byly tzv. párové glóby, zemský a nebeský glóbus stejné velikosti i tvaru, pocházející z jedné dílny. Párové glóby byly součástí knihoven ${ }^{50}$ a pracoven a kromě vzdělávacího měly i dekorační charakter. Symbolem astronomie byla armilární sféra, model nebeské sféry tvořený významnými kružnicemi jako jsou rovník, obratníky, ekliptika a poledníky a světovou osou. Armilární sféra sloužila jako učební pomůcka k demonstraci planetárního systému, pohybů Země, Slunce a hvězd. K výkladu a demonstraci v geografii a astronomii se používaly další zařízení jako teluria a planetária. Jednalo se o mechanické modely, které zobrazovaly naši planetární soustavu nebo její část.

49 Georg Friedrich Brander (1713-1783) založil řemeslnou dílnu v Augsburgu. Její program zahrnoval výrobu mechanických a optických prrístrojů pro meteorologii, geodézii a astronomii. Roku 1737 vyrobil i první zrcadlový dalekohled v Německu.

50 Nejznámější knihovní sbírka glóbů u nás je uložena v barokním sále Klementina, je v ní celkem 14 glóbů barokních a empírových. Na čele jsou obří kusy, párové glóby od Caspara Pfliegera (průměr $127 \mathrm{~cm}$, pevně zabudované do výbavy sálu) a pár od Vincenza Coroneliho (průměr $108 \mathrm{~cm}$ ). 


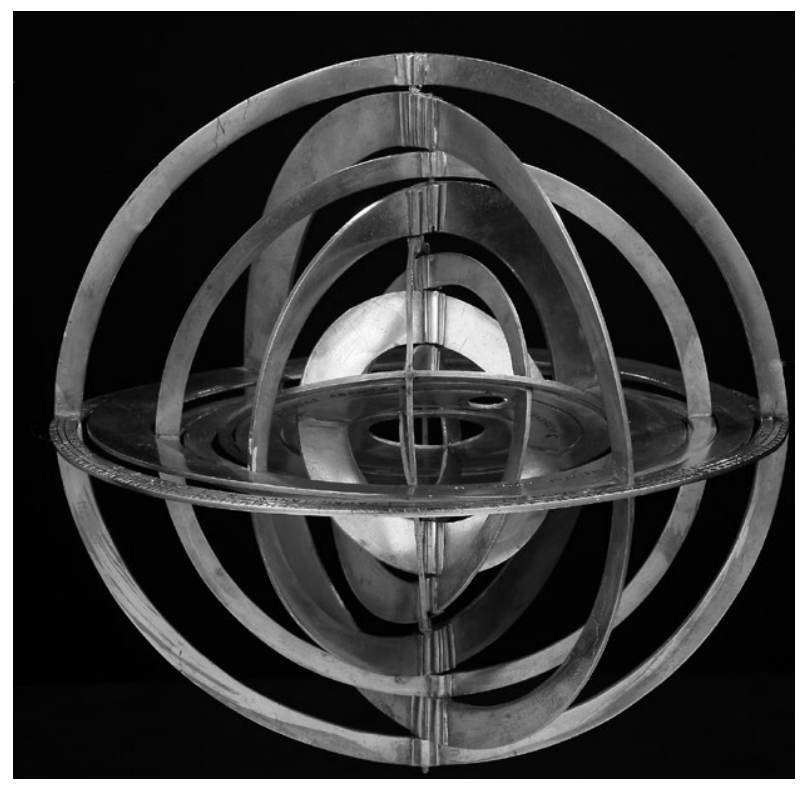

Obr. 9 Planetárium (inv. č. 17148), nesignováno, 16. století, průměr 215 mm (foto Kateřina Uksová)

Naprosto výjimečným kusem je planetárium, pocházející z 16. století. Je určeno k demonstraci pohybu Slunce a Měsíce z geocentrického hlediska. V jeho konstrukci je využito prstenců, které vyplňují mezeru v prstenci předcházejícím a nechávají právě tolik místa, aby se v nich mohl volně otáčet další vnitřní prstenec. Ke každému prstenci je připevněn kolmý prstenec s ním shodný, spojený osou s předchozím vnějším i následujícím vnitřním prstencem. V tomto planetáriu jsou obsaženy tři systémy, vnější systém představuje sféru stálic. Je tvořen jediným prstencem v rovině ekliptiky s popisem znamení zvířetníku: „ARIES, TAVRUS, GEMINI, CANCER, LEO, VIRGO, LIBRA, SCORPIVS, SAGITTARIVS, CAPRICORNVS, AQVARIUS, PISCES“. Druhý systém (střední) je umístěn uvnitř a je sluneční, další systém (vnitřní) je zemský.

Mezi glóby vynikají dva modely jiného tělesa, než je naše Země. Jedná se o Měsíc a Mars. Na měsíčním glóbu v měřítku 1 : 23000000 je zakreslena přivrácená strana včetně souřadnicové sítě poledníků a rovnoběžek. Soupis 343 kráterů je vytištěn na odvrácené straně Měsíce s údaji o vzdálenostech, rozměrech, plochách a oběžné době Měsíce. Na glóbu je nápis „Globe de la lune. Dressé sous la direction de Camille Flammarion Par C. M. Gaudibert. E Bertaux Editeur a Paris. Echelle 1 : 23000000“.

Obraz Marsu zobrazuje oceány, moře a kontinenty pojmenované po významných vědcích, převážně astronomech. Glóbus obsahuje nápis Globe géographique de la Planète Mars d'après Camille Flammarion. E. Bertaux Editeur 25. Rue Serpente Paris, údaje Marsu (průměr, délka roku, sklon osy) a jeho vzdálenosti od Slunce a Země. Glóbus má jižní pól nahoře a severní na opačné straně, jak byl Mars viděn v astronomickém dalekohledu ze Země. V poslední čtvrtině 19. století pozorovali rudou planetu astronomové a vytvářeli její kartografický obraz, nejprve zhotovovali mapy, později i glóby. Mezi nimi 


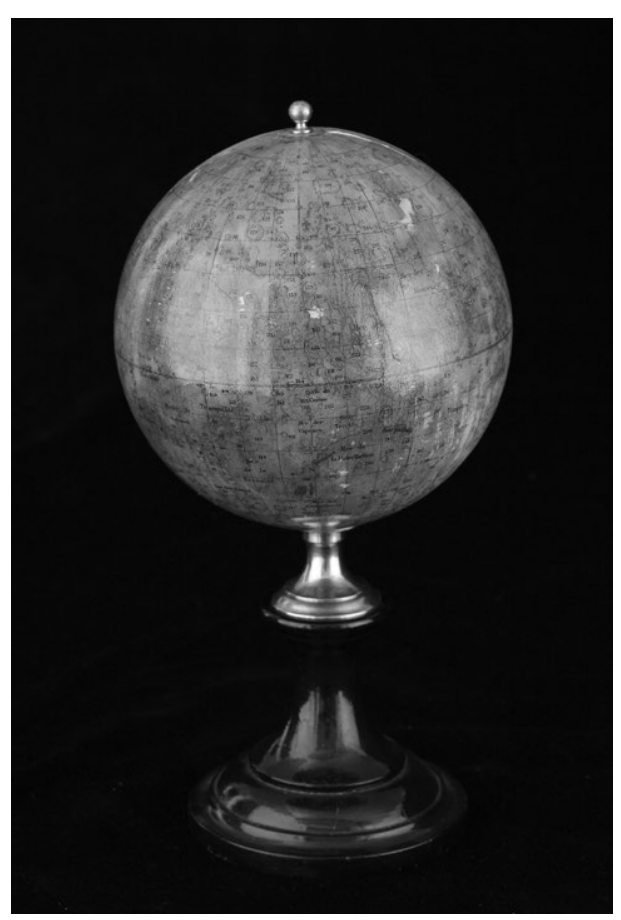

Obr. 10a Glóbus Měsíce (inv. č. 17153), Camille Flammarion, Paříž, 1880-1900, průměr $150 \mathrm{~mm}$ (foto Kateřina Uksová)

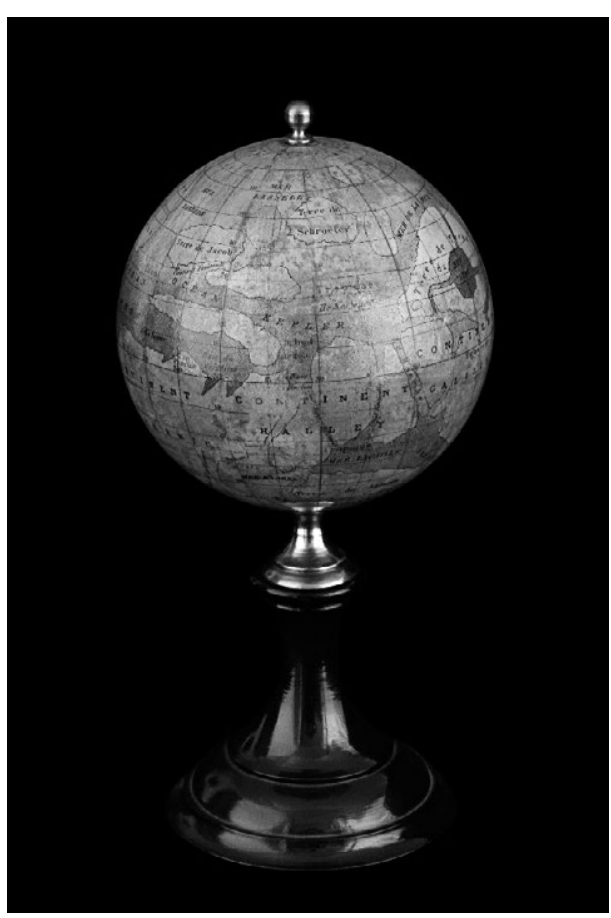

Obr. 10b Glóbus Marsu (inv. č. 17154) Camille Flammarion, Paříž, 1884, průměr 110 mm (foto Kateřina Uksová)

byl i francouzský astronom C. Flammarion. ${ }^{51}$ Velký zájem o pozorování a studium Marsu vyvolala jeho kniha La planète Mars.

Součástí akvizice byla i jubilejní mosazná plaketa na počest Camille Flammariona. Na plaketě je jeho reliéfní portrét s pařížskou hvězdárnou a nápisem: „Jubilé Scientifique A Camille Flammarion Ses Admirateurs, ses Amis". Kromě toho je v levém dolním rohu naznačena planeta Mars a nad ní je Saturn spolu se jménem autora a datem vydání „A. Zeitlin 1911“. Plaketa je zhotovena v secesním slohu s postavami dvou andělů, jeden klade vavř́n na hlavu Flammariona, druhý ukazuje na hvězdu.

Výjimečný demonstrační přístroj představuje model Slunce ve středu a čtyři zemské glóby na ramenech. Glóby znázorňují postavení Země ve čtyřech ročních obdobích. Předmět ukazuje př́icinu střídání ročních období - sklon zemské osy k oběžné dráze kolem Slunce (ekliptika). V létě je ke Slunci přivrácena severní polokoule, na jižní polokouli je zima. $V$ zimě je to naopak. $V$ době rovnodennosti (na jaře 20. 3. a na podzim 23. 9.) jsou obě polokoule osvětleny stejně a den i noc trvá 12 hodin na celé Zemi. Text na glóbech je německý „Die Erde gezeichnet von Otto Delitsch. Herausgegeben u. Druck v. J. Felkl in

51 Nicolas Camille Flammarion (1842-1925), astronom, spisovatel a velký popularizátor astronomie. V roce 1882 založil hvězdárnu v Juvisy u Paříže, roku 1887 založil Francouzskou astronomickou společnost. 


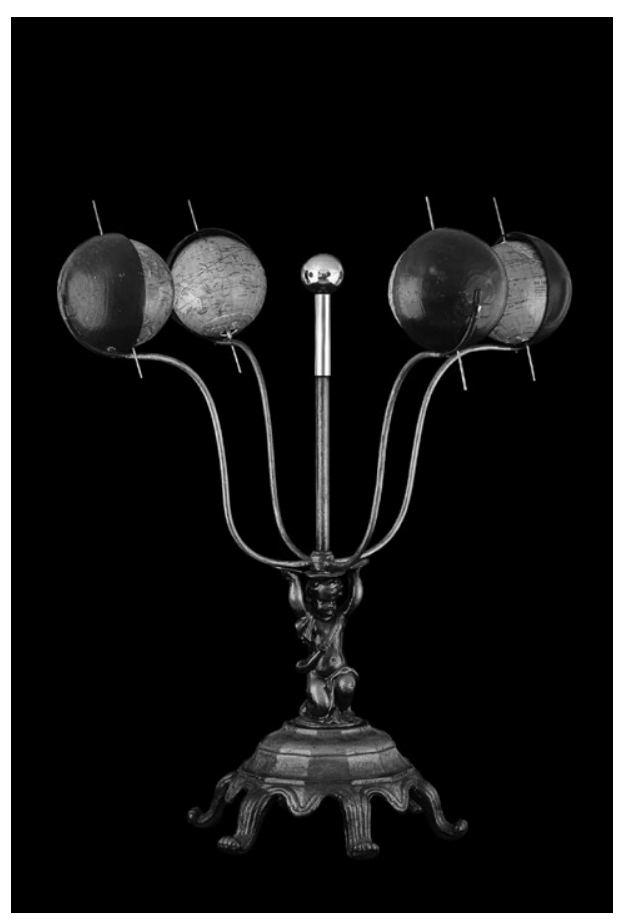

Obr. 11a Přístroj se čtyřmi glóby (inv. č. 17169), Jan Felkl, Praha, autor glóbů Otto Delitsch, Lipsko 1852-1870, glóby průměru $115 \mathrm{~mm}$ (foto Kateřina Uksová)

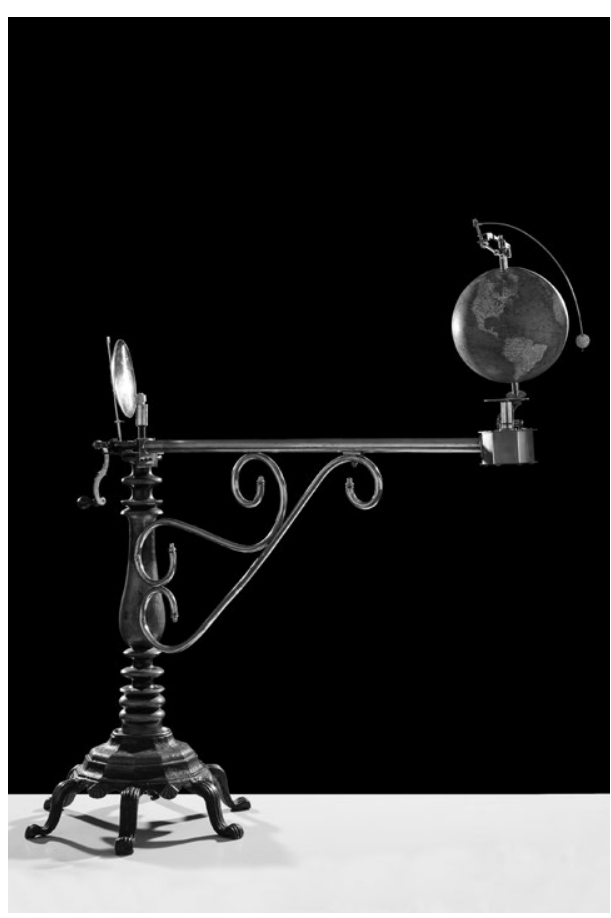

Obr. 11b Telurium (inv. č. 17143), Jan Felkl, Praha, průměr glóbu $220 \mathrm{~mm}$ (foto Patrik Sláma)

Prag“. Předmět vyrobila na počátku své existence známá firma na demonstrační pomůcky Jana Felkla (1817-1887). Ta v té době ještě sídlila v Praze, později (roku 1870) přesídlila do Roztok.

Telurium ${ }^{52}$ je demonstrační př́ístroj známý především ze škol. Sloužilo k předvedení základních pohybů soustavy Slunce, Země a Měsíc. Na masivním stativu je zasazen sloup s převodovým zařízením a klikou. Otáčením klikou se pohybuje zeměkoulí kolem osy i kolem Slunce, jde tedy o denní i roční pohyb Země. Slunce je reprezentováno hořící svíčkou v ose teluria. Současně se pohybuje na čtvrtkruhovém raménku model měsíce kolem země. Text na zeměkouli je německý „Die Erde herausgegeben von J. Felkl in Prag. Entwurf und Zeichnung von Otto Delitsch. Lithographie und Farbendruck des geogr. lith. Institutes von J. Felkl in Prag“. Jedná se o velký neobvyklý model teluria rozměrů $1290 \times 1420 \times 540 \mathrm{~mm}$.

Další předměty pocházejí z kartografické tvưrčí dílny Josefa Jüttnera, ${ }^{53}$ vojenského kartografa působícího v Praze. K zemskému glóbu o průměru $320 \mathrm{~mm}$ z roku 1822 vytvořil

52 Název telurium je odvozen od latinského slova tellus - Země.

53 Josef Jüttner (1775-1848), důstojník rakouské armády, vytvořil roku 1816 první mapu Prahy na podkladě geometrického vyměřování. 


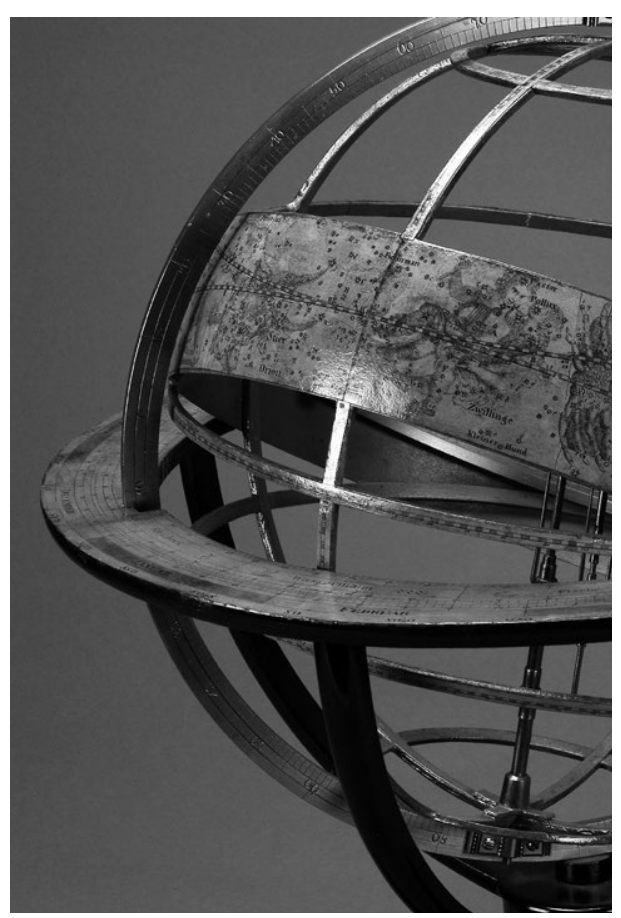

Obr. 12a Armilární sféra, detail (inv. č. 17142), Josef Jüttner, 1828, průměr $320 \mathrm{~mm}$ (foto Kateřina Uksová)

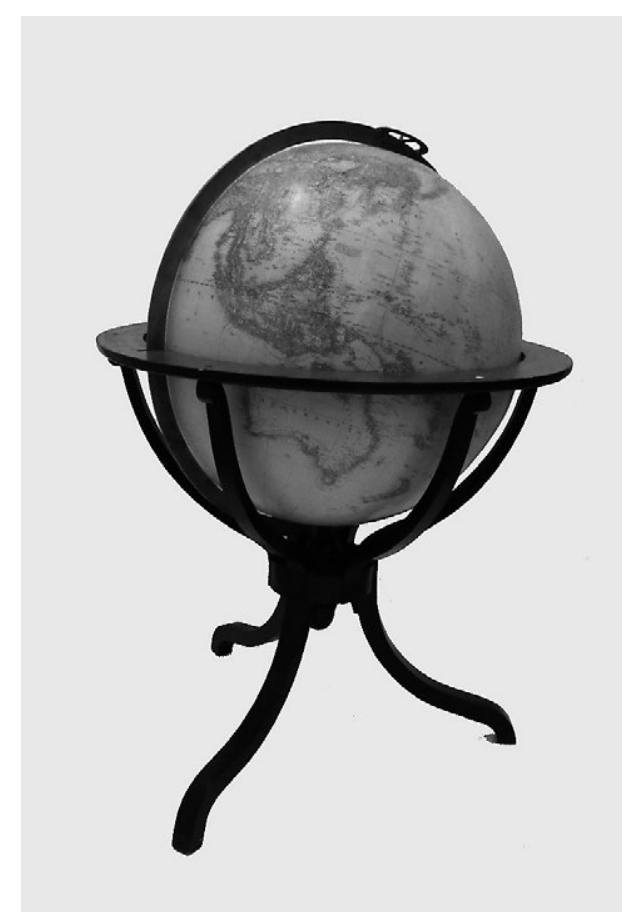

Obr. 12b Zemský glóbus (inv. č. 17177), Josef Jüttner, 1839, průměr $560 \mathrm{~mm}$ (foto Stanislav Dvořák)

párový hvězdný glóbus (1824) a později (1828) i armilární sféru. Sféru je možné použít k výkladu geocentrické i heliocentrické teorie planetární soustavy. Obsahuje model Slunce, planet Merkur, Venuše, Země s Měsícem, Mars, Jupiter, Saturn a Uran. Vlastní sféru tvoří soustava kolurů, polárních kruhů, obratníků, rovníku a ekliptiky. Na širokém pásu ekliptiky je zobrazena část oblohy s postavením hvězd k éře roku 1850.

K stěžejnímu dílu kartografa Jüttnera patří zemský glóbus průměru 2 stop $(560 \mathrm{~mm})$, největší jaký z dílny tohoto autora vyšel. Zeměpisný obraz zdůrazňuje horstvo a vodstvo celého světa. Nápis na jižní polokouli: „Erdkugel von 2 Wiener Schuh im Durchmesser nach den neusten geographischen Bestimmungen entworfen und herausgegeben von Joseph Jüttner Oberstlieutenant im kais: königl. Bombardier Corps, zu Wien im Jahre 1839. In Kupfer gestochen von Bernhard Biller, Johan David“. Glóbus je opatřen kovovým meridiánovým kruhem a je uložen $v$ dřevěném třínohém stativu s šesti vzpěrami a obzorníkovým kruhem.

Další originální pomůcka je uranoskop sloužící k vyhledávání hvězd na obloze. Jeho základní částí je zařízení $\mathrm{k}$ nastavení glóbu do správné polohy. Nařídí se výška pólu k souladu osy glóbu se světovou osou a glóbem se otočí podle data a hodin dne. Po seřízení odpovídá postavení glóbu pozici hvězdné sféry. Pomocí „hledače hvězd“ se nastaví požadovaná hvězda (souhvězdí) na glóbu a průhledítky se pak hledá na obloze. Autorem návrhu 


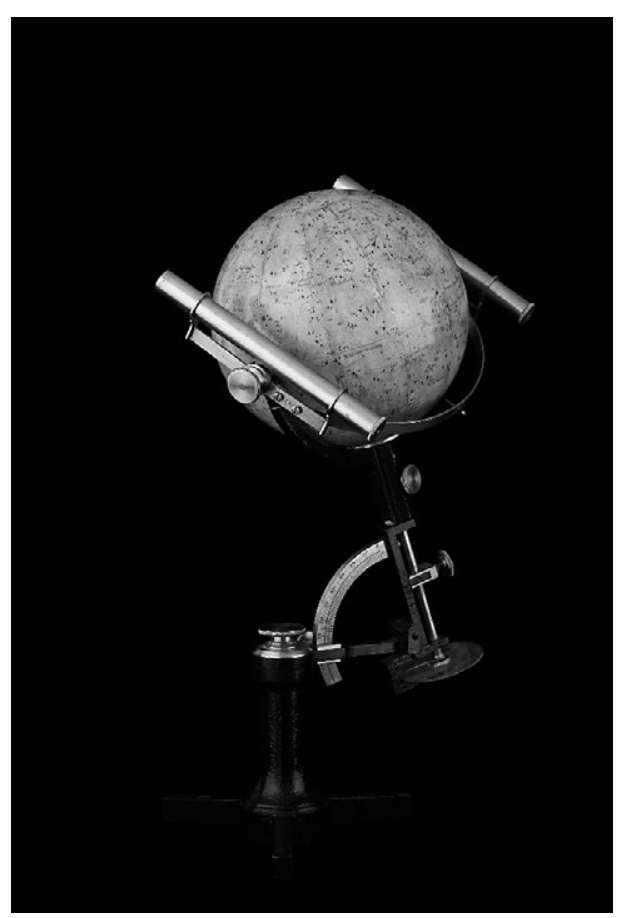

Obr. 13a Uranoskop (inv. č. 17168), J. G. Böhm, V. Grund, Praha, 50.-60. léta 19. století, glóbus průměru $160 \mathrm{~mm}$ (foto Kateřina Uksová)

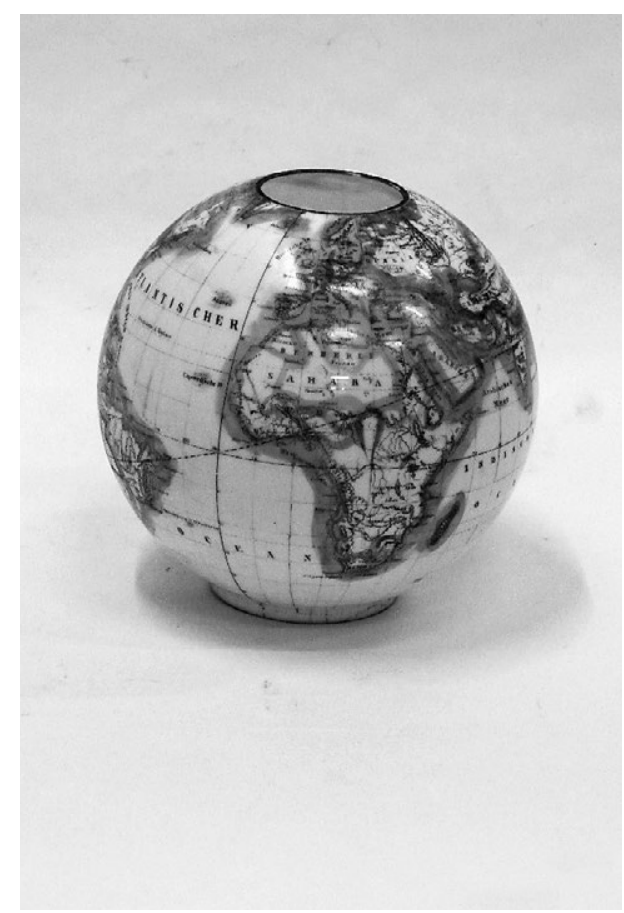

Obr. 13b Glóbus zeměpisný na skleněném stínítku (inv. č. 17150), Stelzig, Kittel \& Co, Kamenický Šenov, kolem 1882, průměr $180 \mathrm{~mm}$ (foto Stanislav Dvořák)

a konstrukce uranoskopu a hvězdného glóbu je astronom Josef Georg Böhm, ${ }^{54}$ zařízení sestrojil mechanik Václav Grund.

Zajímavostí sbírky je skleněné stínítko na petrolejovou lampu. ${ }^{55}$ Podobné stínítko se vyrábělo i pro elektrické lampy. Stínítko bylo nasazeno na lampě spodním otvorem a z horního otvoru vycházel skleněný válec pro plamen. Na kulovém stínítku z mléčného skla je překreslen původně litografický obraz Země. Obrysy států jsou značeny hnědou, zelenou, fialovou a modrou barvou. Nápisy, poledníky a rovnoběžky hnědou barvou. Oceány a moře jsou ohraničeny světle šedou barvou. Autor předlohy zemského glóbu není znám.

Mezi demonstrační předměty řadíme i stolní hodiny s názornou ukázkou astronomických jevů a mapami hvězdné oblohy. Hodiny jsou označeny: „L. Deichmann’s Astronomisches

54 Dr. Josef Georg Böhm (1807-1868) po studiích na univerzitě v Praze pracoval na hvězdárně ve Vídni a Budapešti, učil na univerzitě v Salzburgu. V roce 1852 byl jmenován ředitelem pražské hvězdárny a profesorem astronomie na univerzitě.

$55 \mathrm{Viz}<\mathrm{https}$ //www.dorotheum.com/cz/aukce/aktualni-aukce/kataloge/list-lots-detail/auktion/10836-starozitnosti-historicke-vedecke-pristroje-a-globusy/lotID/337/lot/1764045-seltener-beleuchtbarer-globus-aus-glas -die-globus-lampenkugel.html> (ověřeno 30. 7. 2018). <http://www.odbornecasopisy.cz/svetlo/casopis/tema /osvetlovaci-sklo--16373> (ověřeno 30. 7. 2018). 


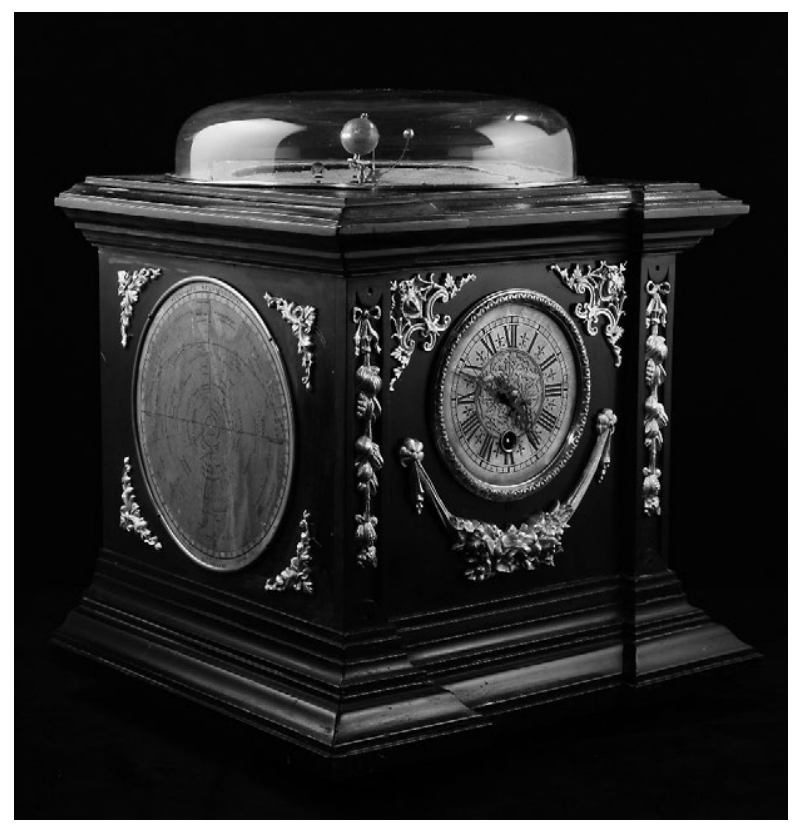

Obr. 14 Astrochronometr (inv. č. 17165), L. Deichmann, Kassel, 1890, rozměry $425 \times 380$ $\times 340 \mathrm{~mm}$ (foto Kateřina Uksová)

Chronometer Cassel“. Na horní ploše skř́iňky je umístěno telurium s modelem Slunce. Telurium demonstruje denní a roční pohyb Země a pohyb Měsíce kolem Země a své osy. Telurium je doplněno otočným kotoučem s elipsami znázorňujícími dráhy planet Merkuru a Venuše. Po obvodu planetária je prstenec s kalendářními stupnicemi a eliptickou dráhou Marsu. Hodinový stroj má Grahamův kotvový krok a krátké kyvadlo na pružinovém závěsu. Svojí přesností odpovídá kvalitnějšímu provedení interiérových stolních hodin s pérovým pohonem. Pro demonstrační účely je tento stupeň přesnosti postačující.

\section{Geodetické a navigační přístroje}

Vedle astronomických instrumentů se současně vyvíjely i přístroje pro vyměřování zemského povrchu. Mezi nejznámější patří teodolit, ${ }^{56}$ geodetická pomůcka k měření vodorovných a svislých úhlů. Vychází z jednoduchých pomůcek - geometrického čtverce a měřických astrolábů, půlkruhového a kruhového. Teodolit popsal poprvé roku 1571 Leonard Digges, jednalo se o vodorovný kruh dělený na $360^{\circ}$ a svislý půlkruh. K cílení teodolitu sloužilo záměrné pravítko (alhidáda), od poloviny 18. století se stal zaměřovačem dalekohled. K odečítání úhlů se používaly dělené kovové kruhy, později skleněné kruhy. Součástí

56 Název vznikl spojením a zkomolením anglického členu „the“ a arabského slova „al idada“, značícího otáčivou část přístroje. 


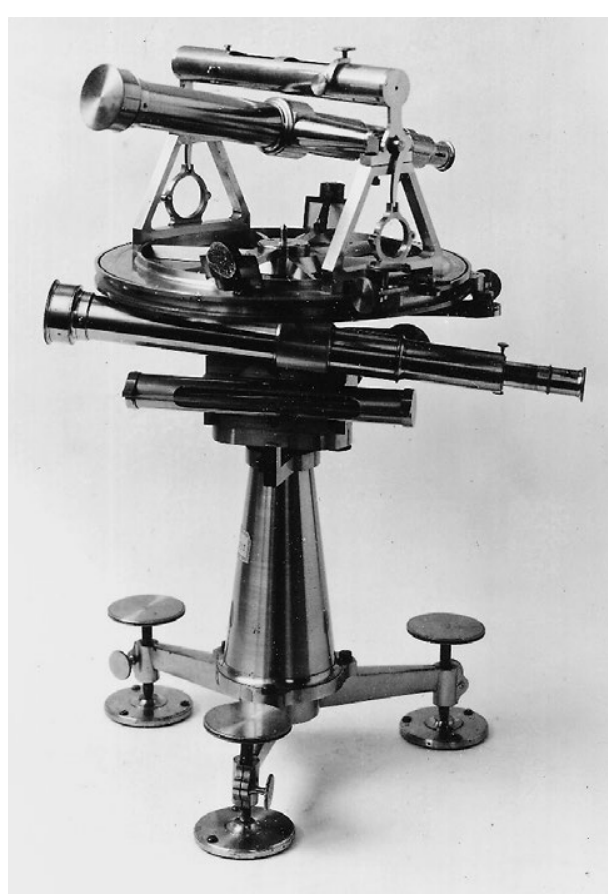

Obr. 15a Teodolit (inv. č. 17139) Georg Friedrich Reichenbach, Joseph Utzschneider a Joseph Liebherr, Mnichov, po roce 1800, výška 460 mm (foto Patrik Sláma)

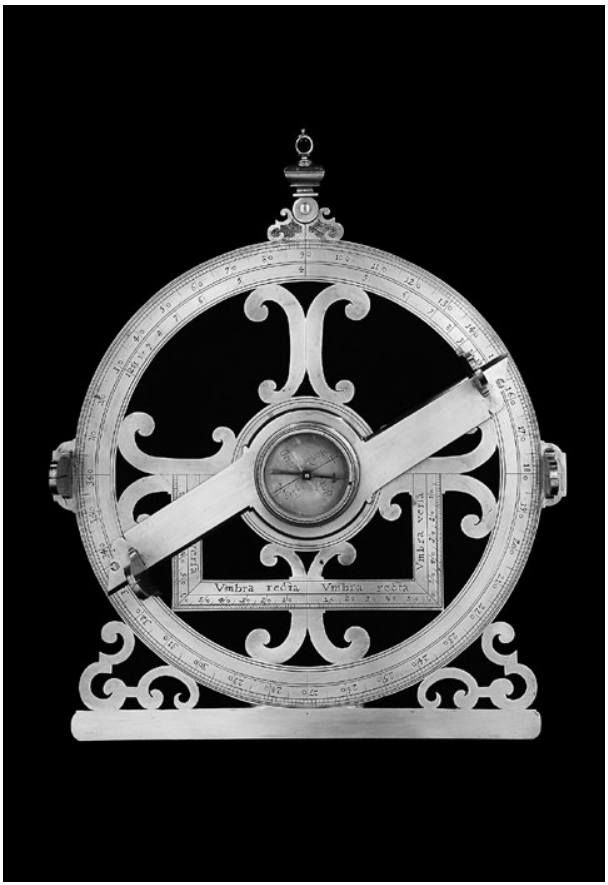

Obr. 15b Námořní astroláb (inv. číslo: 17182), Petrus de Heubder, Antverpy, počátek 17. století, kruh průměru $194 \mathrm{~mm}$, celkové rozměry $250 \times 215 \times 50 \mathrm{~mm}$ (foto Kateřina Uksová)

úhloměrných přístrojů se stal kompas, který umožňoval kromě měření magnetických azimutů i měření magnetické deklinace. ${ }^{57}$ Univerzálním př́istrojem byla Jakubova hůl, jednoduchá pomůcka $\mathrm{z} 13$. století, která byla založena na podobnosti trojúhelníků. Běžně se používala v geodetickém měření i v námořní navigaci. Jejím nástupcem se stal v 18 . století zrcadlový sextant, který se použival k určení zeměpisné šiřky na moři. Zeměměřiči považovali kapesní sextant (odvozený ze zrcadlového) za nezbytný při měření svislých a vodorovných úhlů během trigonometrických měření. Bez něho by žádný zeměměřič 19. století nevyrazil do terénu.

Jeden teodolit pochází z doby přelomu 18. a 19. století, kdy byl ředitelem hvězdárny Alois Martin David, astronom a geodet evropského formátu. Výsledky měření, na nichž se zásadním způsobem podílel, dovolily vydat prvé nezkreslené mapy, založené na astronomicky zjištěných zeměpisných souřadnicích význačných míst v Čechách a sousedních zemích. Na teodolitu je nápis „Reichenbach, Utzschneider u. Liebherr in München“. Limbový kruh průměru $248 \mathrm{~mm}$ má úhlovou stupnici $0-360^{\circ}$ dělenou po $5^{\prime}$. Úhel se odečitá pomocí vernierů (diference $4 "$ ) ve čtyřech protilehlých polohách. Na limbu jsou připevněny

57 Úhlový rozdíl mezi směry zeměpisného a magnetického severního pólu Země, který se mění v průběhu času. 
dva nosníky osy dalekohledu se sázecí trubicovou libelou. Limbový kruh lze takto používat v horizontální poloze. Díky sklopnému zařízení je možné limbový kruh otočit do vertikální polohy. $V$ tom př́padě slouží dalekohled a libela umístěné pod limbem. Př́strojem lze měřit úhly s vteřinovou přesností a sloužil k triangulačním měřením.

Mezi výjimečné př́stroje patří astroláby, jak původní astronomické verze, ${ }^{58}$ tak i jejich odvozeniny pro geodetické a navigační měření. Jedním z nich je námořní astroláb určený k měření výškových úhlů. Podle masivní konstrukce je zřejmé, že byl sestrojen k měření na rozbouřeném moři a v silném větru. Námořní astroláb byl poprvé použit portugalskými mořeplavci na konci 15. století. Sloužil k určení zeměpisné šířky lodi na moři měřením výšky poledního Slunce nebo meridiánovým měřením výšky hvězdy známé deklinace spolu s využitím astronomických tabulek. Astroláb je možné použít i k měření vodorovných úhlů (azimutů) díky kompasu. Limbová stupnice je dělena na $360^{\circ}$, další stupnice označuje úhly a délky stran pravidelných mnohoúhelníků. $V$ dolní části kruhu je stínový čtverec pro svislé stupnice Umbra versa (stíny vodorovného gnómonu) a vodorovné stupnice Umbra recta (stíny svislého gnómonu). Na kruhu je připevněn pár pevných průhledítek u hodnot $180^{\circ}$ a $360^{\circ}$. Ve středu je umístěn kompas, kolem něhož se otáčí záměrné pravítko (alhidáda) s párem jednoduchých vizírů. Na rubu př́stroje je signatura výrobce „Fecit Antverp. Petrus de Heulders“. Př́stroj je zdoben tvarováním vzpěr a závěsu.

Pokusem o sjednocení měr byly tereziánské patenty z let 1756 a 1764, které zaváděly vídeňské (dolnorakouské míry) po celé monarchii ve všech oborech. Bylo důležité, aby míry byly stabilní a platily univerzálně. Na patenty navazuje sáh, který byl oficiální délkovou mírou. Sloužil jako etalon $\mathrm{k}$ definování a porovnání měrové jednotky a zakládání dalších kopií. Latinský nápis na měřítku praví: „,míra vídeňského sáhu a lokte zřizena Františkem a Marií Terezii 1756“. Tento oficiální etalon uvádí vztah vídeňského sáhu a lokte ke stejným mírám v dalších částech monarchie (Čechy, Slezsko, Morava, Tyrolsko). Správcem míry byl Josef Franz, člen jezuitského řádu. Základní délkovou jednotkou dvanáctkové soustavy byl sáh $(1,896 \mathrm{~m})$, který měl šest stop, stopa 12 palců, palec 12 čárek. 4000 sáhů tvořilo délku 1 vídeňské míle (7586 m). Důležitou roli sehrála tato měrová soustava v katastrálním mapování, kdy požadavek zobrazit 40 sáhů v terénu jako jeden palec $(26,34 \mathrm{~mm})$ na mapě dává měřítko $1: 2880$, známé dodnes. Rakouské míry oficiálně platily v letech 1764-1876.

Ke zkoušení nivelačních př́strojů patří zařízení $\mathrm{k}$ rektifikaci ${ }^{59}$ libel $\mathrm{z}$ augšpurské dílny Georga Friedricha Brandera. Zařízení je doplněné o dalekohled, takže může sloužit i jako aparát pro přesnou nivelaci, určování výšek bodů měřením převýšení mezi sousedními body. Základem zařízení je dřevěná podložka (ve tvaru stolku) s nožičkami v rozích. $\mathrm{Na}$ každé straně jsou připevněny dva můstky, jeden je opatřen elevačním šroubem ke změně sklonu. Číselník elevačního šroubu je dělený na 60 " (úhlových vteřin) s dílky po $1 "$ ". Na číselníku je vyryt nápis „G. F. Brander fecit Aug. Wind“. Na můstcích je umístěn nosník $\mathrm{s}$ lůžky k uložení zkoušeného dalekohledu nebo libely. Toto zařízení sloužilo k seřízení osy

58 V Čechách se nachází pouze čtyři astroláby, v NTM (nesignovaný, kolem 1450), Národním muzeu (G. Hartmann, 1532), Západočeském muzeu v Plzni (G. Hartmann, 1525) a Moravské galerii v Brně (G. Mercator, kolem 1545).

59 Oprava zařízení tak, aby byly splněny všechny osové podmínky. Nivelační libela odpovídá vodorovné záměře nivelačního př́stroje. 
trubicové libely s optickou osou dalekohledu, a to tak, aby byly rovnoběžné. V praxi se toho docílilo tím, že se v určité vzdálenosti od dalekohledu postavila nivelační lat', krabicová libela se urovnala rektifikačním šroubem a přečetla se hodnota na lati. Poté se dalekohled obrátil a na lati se přečetla nová hodnota. $Z$ průměru čtení a ze vzdálenosti latě od stroje se vypočetl úhel, o který se opravila mikrometrickým šroubem výška libely.

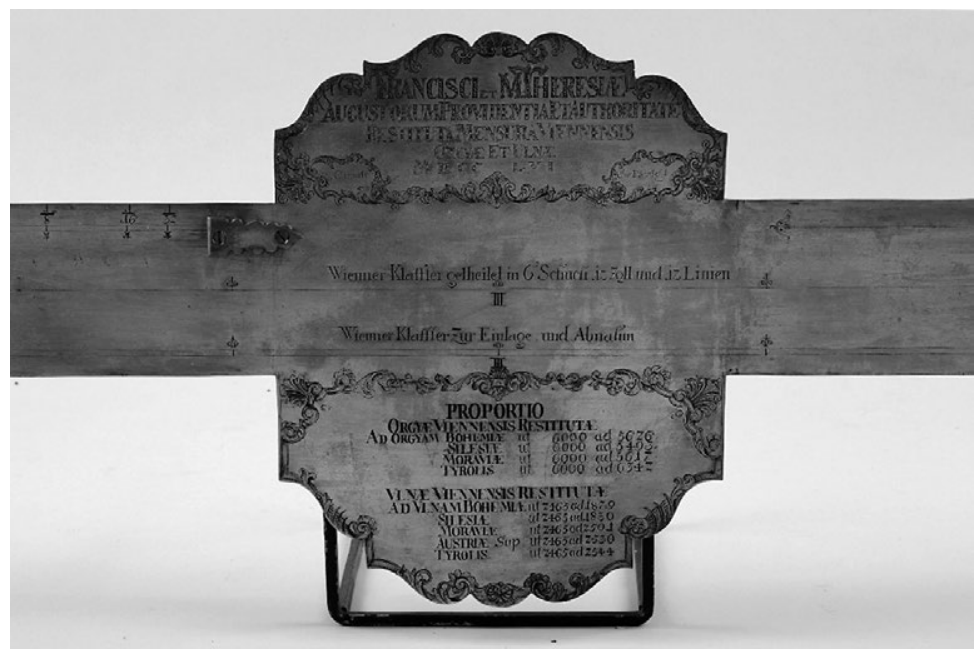

Obr. 16a Etalon vídeňského sáhu, detail (inv. č. 17196), výrobce neoznačen, 1756, délka $2190 \mathrm{~mm}$ (foto Kateřina Uksová)

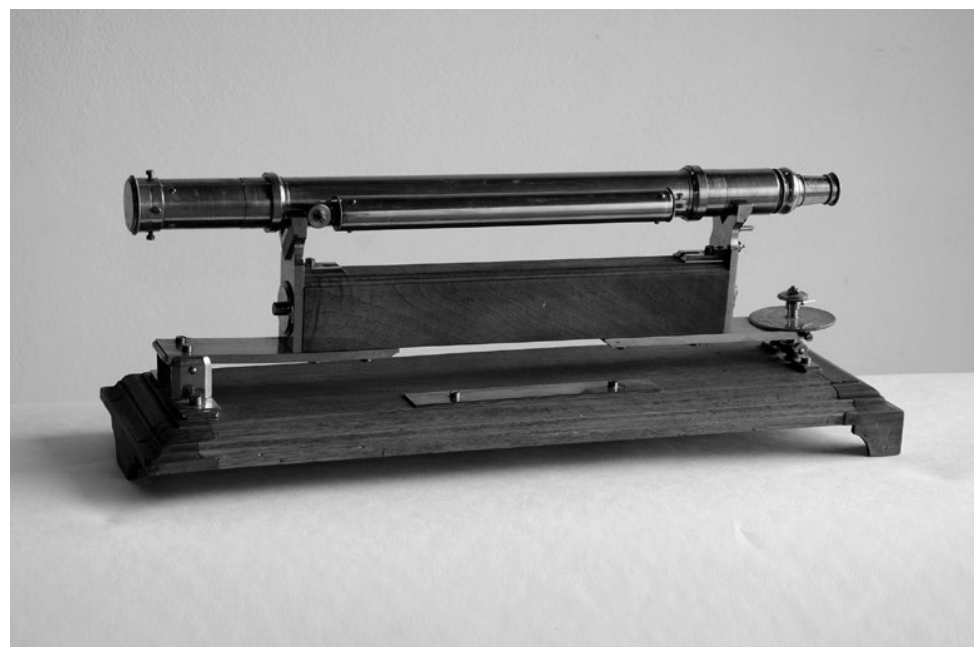

Obr. 16b Nivelační rektifikační prístroj (inv. č. 17122), G. F. Brander, Augsburg, délka dalekohledu 490-530 mm (foto Stanislav Dvořák) 


\section{Hodiny}

Na žádné astronomické observatoři, tedy ani v Klementinu, nemohly chybět astronomické hodiny. Astronomové potřebovali k určení pozice hvězd nejen přesné pozorování dalekohledem, ale i nejlepší hodiny $\mathrm{k}$ měření času. Na hvězdárně v Klementinu působil mimo jiné hodinář Josef Kossek, ${ }^{60}$ který se věnoval astronomickým hodinám. Do sbírky NTM byla předána $\mathrm{v}$ roce 1951 kolekce devíti kusů hodin, včetně astronomických sekundérů, stojacích podlahových hodin, kapesního chronometru a roštových kyvadel. Zajímavostí je předání jednoho stroje věžních hodin z věže Klementina do NTM dlouho před popisovanou akvizicí, již v roce 1929.

Kyvadlové hodiny se vyznačují největší přesností mezi mechanickými hodinami. Bylo tomu tak od doby jejich první konstrukce v polovině 17. století až do třicátých let 20. století. Výhodou kyvadla jako oscilátoru měření času je stálá frekvence kyvu a závislost doby kyvu pouze na délce kyvadla. Kyvadlové hodiny byly v 18. a 19. století běžně používány $\mathrm{v}$ domácnostech, úruadech, továrnách a železničních stanicích. Pro velmi přesné měření času však běžné kyvadlové hodiny nestačily. Kolísání teploty přinášelo změnu délky kyvadlové tyče. To bylo odstraněno zhotovením tyče z materiálů s nízkou tepelnou roztažností a dalšími způsoby teplotní kompenzace. Také změna tlaku vzduchu hrála svou roli v přesnosti chodu hodin. Řešením byl mechanizmus na principu aneroidu kompenzující kolísání tlaku. Definitivním vyřešením tohoto problému bylo uzavření hodin do vzduchotěsného pouzdra s mírným vakuem. Typickými znaky přesných hodin byly od druhé poloviny 18 . století kromě teplotní a tlakové kompenzace jednoduchý a přesný stroj se závažím, Grahamův krok a sekundové kyvadlo. $\mathrm{K}$ dosažení doby kyvu jedné sekundy je třeba metrové kyvadlo, přesně $0,994 \mathrm{~m}$. Velmi přesné kyvadlové hodiny byly označovány jako astronomický regulátor a používaly se kromě astronomie $\mathrm{i} v$ geodézii. $\mathrm{V}$ námořní navigaci byl použit jiný typ přesného časoměrného zařízení, lodní chronometr se speciálním chronometrickým krokem. ${ }^{61}$ Špičkovým pracovištěm byla laboratoř měření času, z ní časová služba distribuovala národní čas. Na počátku 20. století dosáhl astronomický regulátor přesnosti zlomků sekund za den.

Astronomické hodiny významného vídeňského hodináře Johanna Philipa Vöttera (1731-1763) nesou charakteristické znaky přesných kyvadlových regulátorů, jak byly ustanoveny v průběhu první poloviny 18. století v Anglii. Jejich konstrukční zásady záhy převzali hodináŕi v Rakousku. ${ }^{62} \mathrm{~K}$ charakteristickým rysům Vötterových sekundérů patřil rám stroje, sestávající z šestiúhelníkových základních desek, Grahamův klidový krok, bimetalické roštové kyvadlo zavěšené na pružinovém závěsu a s krokovým mechanismem spojená popudná vidlice. Č́selníky nesou u strojů této koncepce shodné znaky, velká centrální ručka ukazuje minuty, sekundy indikuje menší ručka na hř́deli krokového kola v horní polovině číselníkové desky. Hodiny lze odečítat v obloukovém výřezu s indexem v dolní části číselníku. Nad spodním okrajem minutové stupnice je v číselníkové desce ještě

\footnotetext{
60 Josef Kossek (1780-1858) patřil mezi přední mechaniky a hodináře, jako první v Čechách sestrojil bimetalické kyvadlo. Jedny Kosskovy hodiny se dnes nacházejí v astronomické věži Klementina, troje další jsou ve sbírce NTM.

61 Autorem lodního chronometru byl v polovině 18. století anglický hodinář John Harrison (1693-1776).

62 Vedle Vöttera také např́iklad Johann Vellauer nebo o generaci mladší Joseph Langhammer.
} 


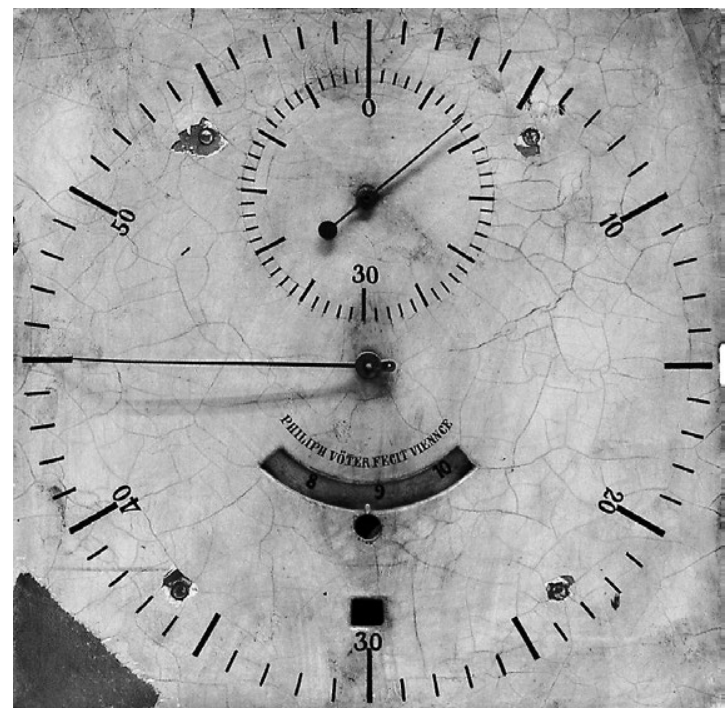

Obr. 17a Astronomický sekundér, detail (inv. č. 18184), 1750-1755, Johann Philip Vötter, Vídeň, stroj $280 \times 260 \times 160$ mm (foto Jan Kříženecký)

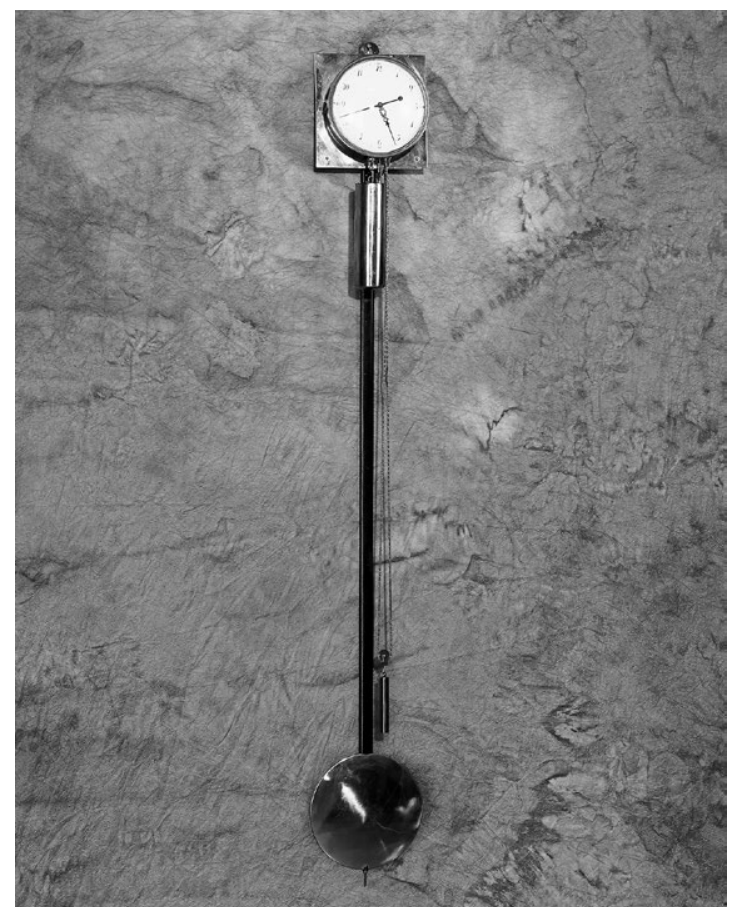

Obr. 17b Astronomický sekundér (inv. č. 17174), Josef Božek, Praha, 1800-1825, $1300 \times$ $150 \times 100 \mathrm{~mm}$ (foto Jaroslav Guth a Martin Tůma) 
okénko kalendářního ukazatele (den v měsíci). Ve sbírce jsou uloženy dva Vötterovy stroje s odlišnou povrchovou úpravou číselníku a způsobem upevnění závěsné konzoly kyvadla.

Dalším předmětem sbírky je astronomický sekundér zhotovený hodinářem a mechanikem pražského Stavovského polytechnického ústavu Josefem Božkem. Stroj má sekundové kyvadlo s tyčí ze smrkového dřeva a Grahamův klidový krok s mosaznou kotvou a stavitelnými ocelovými paletami. Hodiny nemají pro astronomické sekundéry obvyklý číselník s velkou centrální sekundovou ručkou a dvěma menšími excentrickými stupnicemi pro hodiny a minuty. Jedná se o běžný typ číselníku pouze s hodinovou a minutovou ručkou, je ale doplněn akustickou signalizací jednotlivých sekundových intervalů pomocí mosazného zvonku. Další zvonek signalizuje celé minuty. Odbíjení nemá mechanismus s vlastním pohonem. Signalizaci sekund zajištuje rohatka na krokovém kole a minutový signál je iniciován kolíčkem na věnci minutového kola.

Z klementinských sbírek časoměrných př́istrojů pochází také kapesní chronometr významného anglického hodináře Paula Philipa Barauda, který je typickou ukázkou malého přenosného př́istroje $\mathrm{z}$ přelomu 18. a 19. století. Po technické stránce představuje tento chronometr pouze zmenšenou variantu konstrukce námořního chronometru, jak se ustálila na konci 18. století. Má všechny konstrukční prvky, zajišt'ující vysokou přesnost, jakými jsou Earnshawi̊v chronometrový krok, teplotně kompenzovaná bimetalická setrvačka a další nezbytné vybavení. Jedinými odlišnostmi od provedení námořních chronometrů byla u Barraudova prrístroje absence Cardanova závěsu a indikace stupně nátahu hnacího pera. Kapesní chronometr sloužil zejména $\mathrm{k}$ určení zeměpisné délky pro navigační účely na pevnině.

Podlahové hodiny se čtvrt'ovým bitím pražského hodináře Vitalise Zachariase Suttera mají Clementův vratný kotvový krok a sekundové kyvadlo s ocelovou tyčí na pružinovém závěsu. Celý a čtvrt'ový bicí stroj mají početníkový opakovací mechanismus a odbíjejí do

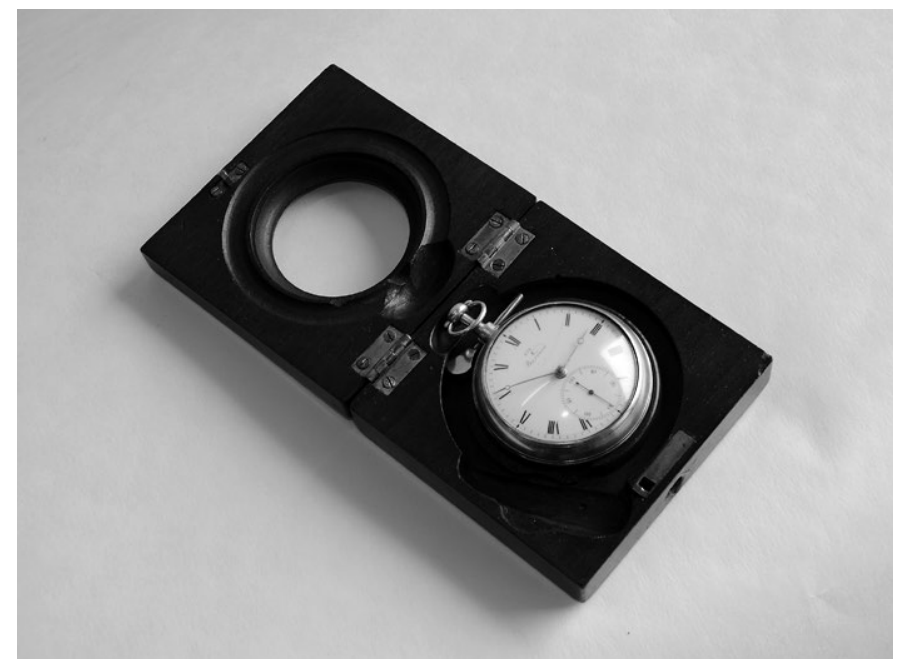

Obr. 18 Kapesní chronometr (inv. č. 17184), Paul Philip Barraud, Londýn, 1780-1820, průměr $55 \mathrm{~mm}$ (foto Jaroslav Guth a Martin Tůma) 


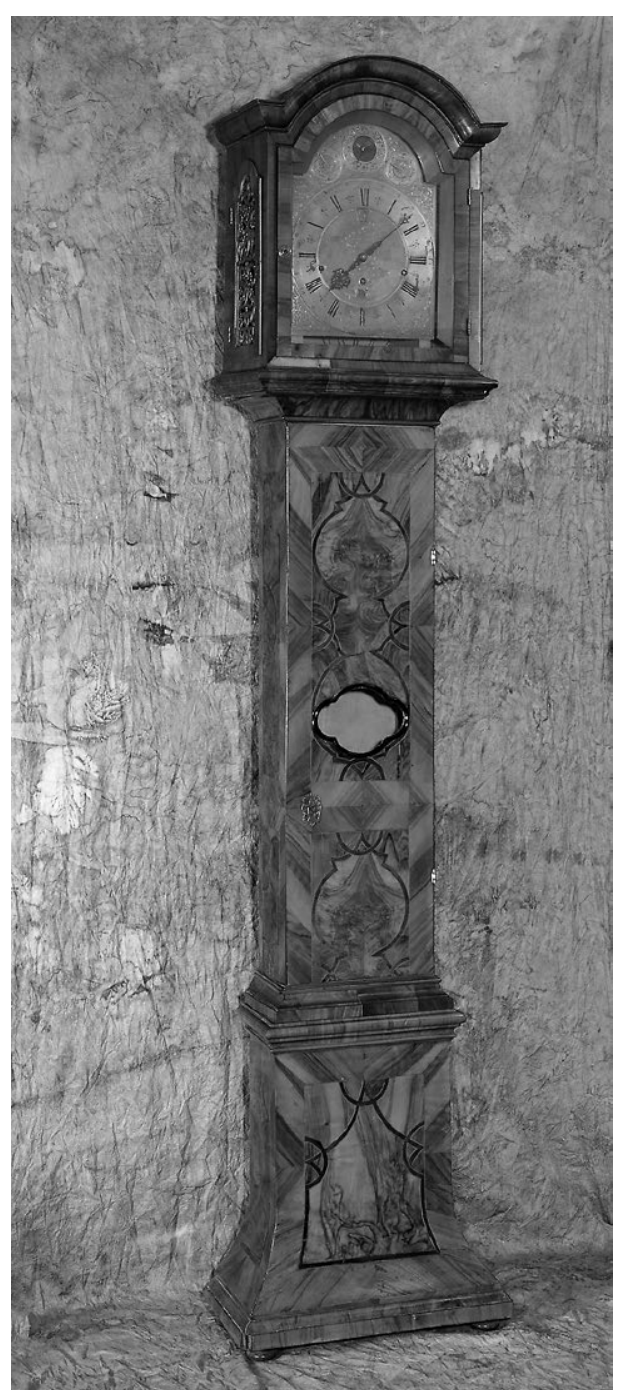

Obr. 19a Podlahové hodiny (inv. č. 18182), Vitalis Zacharias Sutter, Praha, druhá polovina 18. století, $2600 \times 530 \times 280 \mathrm{~mm}$ (foto Jaroslav Guth a Martin Tưma)

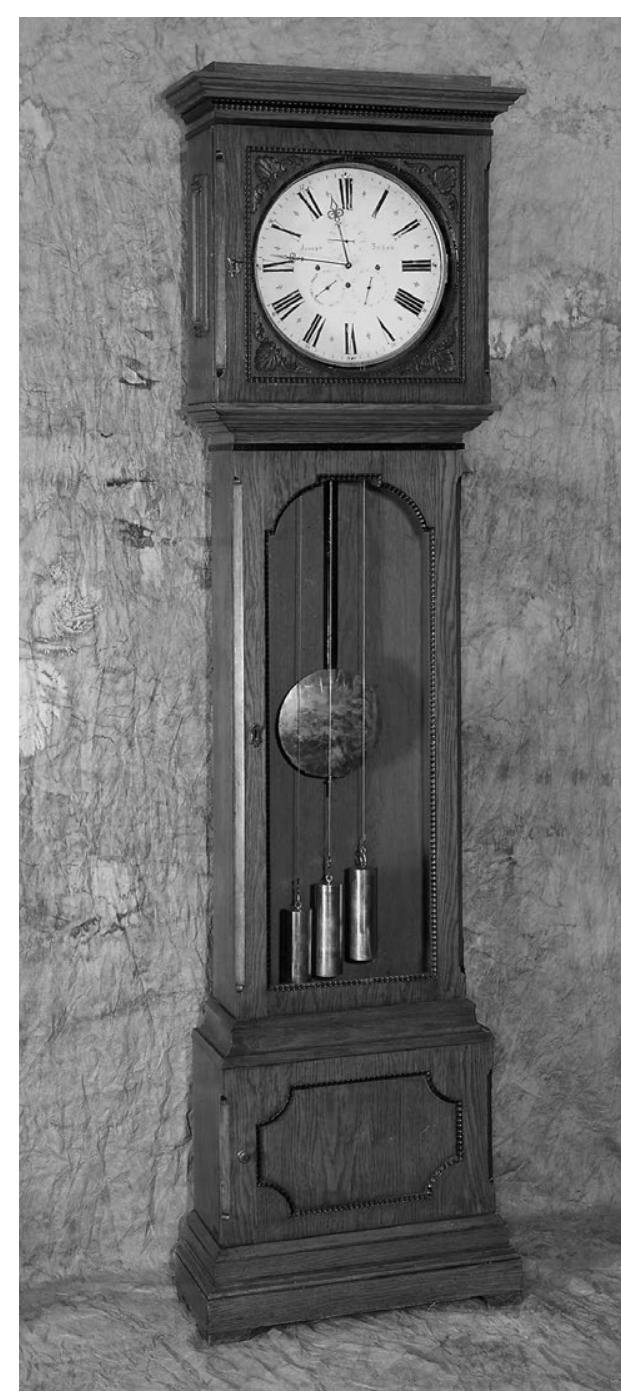

Obr. 19b Stojací podlahové hodiny (inv. č. 18183), Josef Božek, Praha, počátek 19. století, $2300 \times 610 \times 260 \mathrm{~mm}$ (foto Jaroslav Guth a Martin Tůma)

dvou zvonků. Hlavní číselník běžného typu s římskými číslicemi je doplněn dalšími ukazateli. Uvnitř číselníkového prstence jsou dvě okénka. Horní ukazuje název aktuálního měsíce, počet jeho dní a př́slušné zodiakální znamení. Spodní okénko indikuje den v měsíci. Ve štítu číselníkové desky je uprostřed ukazatel měsíčních fází se dvěma ručkami, ukazujícími den v týdnu a znamení ekliptiky. Po obou stranách jsou umístěny ručkové ovladače čtvrtového i celého odbíjení. 


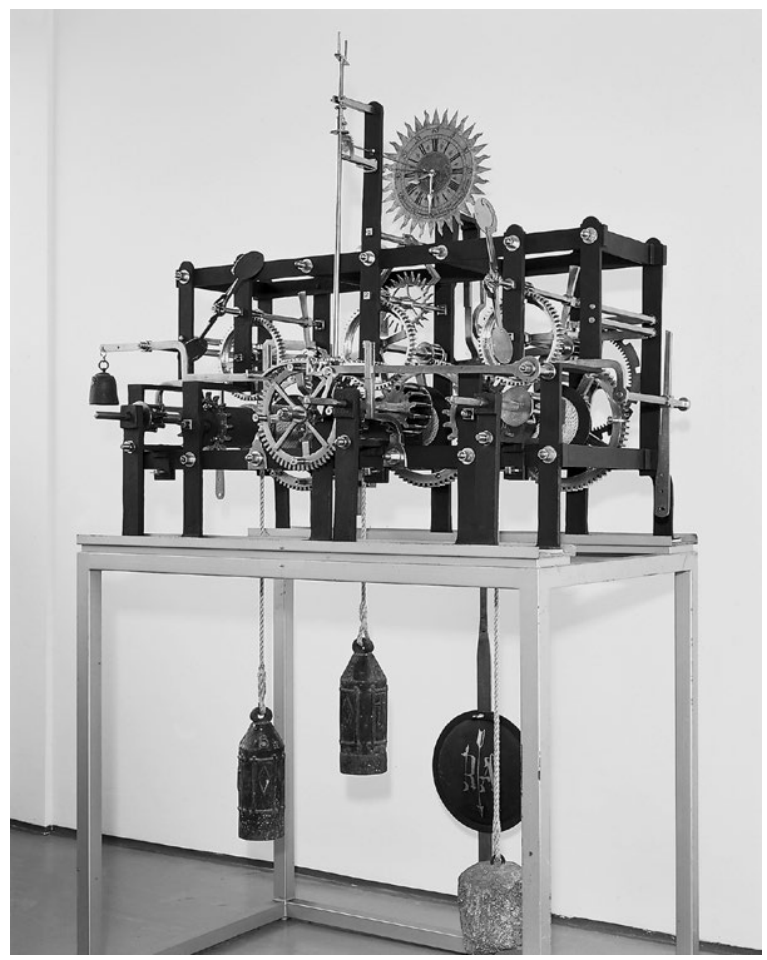

Obr. 20 Stroj čtvrt'ových věžních hodin Klementina (inv. č. 8126), Sebastian Londesperger, Praha, $1736,1720 \times 1400 \times 1040$ mm (foto Jaroslav Guth a Martin Tůma)

Stojací podlahové hodiny se čtvrt’ovým bitím, výrobek známého vynálezce, mechanika a hodináře Josefa Božka, mají Grahamův klidový kotvový krok. Sekundové kyvadlo s dřevěnou tyčí je zavěšeno na pružinovém závěsu. Bicí mechanismus je opakovací, početníkového typu. Klasický číselník s římskými číslicemi a centrálními ručkami je doplněn třemi malými číselníky, nad středem hodinového číselníku je stupnice sekundové ručky, v dolní části potom vedle sebe kalendářní ukazatele dne v týdnu a v měsíci. Hodiny jsou umístěny v jednoduché, střídmě zdobené skř́ni. Provedení stroje odpovídá spíše přesným komerčním hodinám než přístroji pro měření času $\mathrm{k}$ vědeckým účelům.

Pro nás je velmi cenný stroj čtvrt’ových věžních hodin, který pro věž Klementina postavil v roce 1736 pražský hodináŕ Sebastian Londesperger. ${ }^{63}$ Stroj byl do sbírek NTM předán již v roce 1929. Poměrně velký stroj má kovaný rám, jehož části jsou ale již spojovány pomocí šroubů a mosazných matic. Koncepce hodin byla ve své době poměrně moderní, zejména díky zařízení, kompenzujícímu výpadek hnací síly při nátahu a použití tehdy ještě ne příliš známého klidového Grahamova kroku.

Věžní hodiny představují nejstarší typ mechanických hodin, který se objevil v západní Evropě již koncem 13. století. Masivní stroje zhotovované kovářskou technologií se velmi

63 Sebastian Londesperger, královský pražský hodinář, působil v letech 1732-1776 také jako hodinář svatovítský. 
dobře osvědčily na věžích církevních i světských staveb a některé tam slouží dodnes. Je zřejmé, že tyto stroje prošly za celou dobu své existence vývojem a reagovaly na pokrok hodinářské technologie. V mnoha evropských městech byly věžní stroje doplněny astronomickými ciferníky a modely Slunce, Měsíce, dalších nebeských těles a celého nebe. Vzniklé orloje dodaly význam stavbám a demonstrovaly autoritu jednotlivých měst. Od konce 17. století byly věžní hodiny vybaveny kyvadlem a vřetenovým krokem, což mělo zásadní vliv na jejich přesnost. Od 18. století se začaly prosazovat v kovářské technologii změny ve spojování jednotlivých částí, místo klínů byly používány šrouby a matice. Jako materiál rámů se používala litina, u věnců ozubených kol a ložisek hřídelů se užívala mosaz místo železa. Nové technologie umožnily dosažení přesného provedení všech funkčních částí.

\section{Meteorologické a fyzikální prístroje}

Na konci 16. století začaly vědecké výzkumy v oblasti pozorování atmosféry (meteorologie). Slavný italský astronom a fyzik Galileo Galilei konstruoval pomůcku k měření teploty. ${ }^{64}$ Původní kapalinové teploměry naplněné vodou byly později nahrazeny teploměry s lihem a rtutí, stejně tak byly postupně definovány teplotní stupnice (Fahrenheit, Reaumur, Celsius, Kelvin a další). V 17. století se objevila nová zařízení ke zkoumání dalších vlastností a jevů atmosféry. Př́stroj k měření tlaku vzduchu, barometr, vynalezl italský matematik Evangelista Torricelli (roku 1644). Další meteorologická pomůcka anemometr slouží k měření rychlosti větru. Sestrojil ji roku 1667 anglický př́rodovědec Robert Hooke. Díky těmto typům přístrojů a dříve známému vlhkoměru začala doba systematických meteorologických pozorování. První sít’ meteorologických stanic byla založena roku 1652 v italském Toskánsku. V 18. století se zapsalo mezi přední meteorologické stanice Evropy i Klementinum, kde probíhalo standardní vědecké měření vlastností atmosféry.

Do sbírky NTM bylo předáno celkem šestnáct meteorologických prrístrojů. Jediným z nich pocházejícím z 18. století je barometr z doby působení Antonína Strnada ${ }^{65}$ na Královské pražské hvězdárně. Strnad tam pracoval jako adjunkt a roku 1775 zahájil souvislou řadu meteorologických pozorování, čímž navázal na předchozí Steplingova pozorování. ${ }^{66}$ Zasloužil se o zařazení klementinské meteorologické observatoře na přední místo na světě, především zapojením do mezinárodní spolupráce. Začalo tzv. zlaté období meteorologických měření Klementina.

Rtut'ový staniční barometr je signovaný „,Societas Meteorologica Palatina“ 67 a „Carolus Theodor Elector Mussagetes Palatinus 1780“. Byl jedním z kolekce př́strojů, které byly

64 Ke konstrukci teploměru využil Galilei (1564-1642) na počátku 17. století rozpínání a smrštování vzduchu k pohybu obarveného vodního sloupce v připojené trubici.

65 Antonín Strnad (1746-1799) studoval matematiku, fyziku a astronomii na Karlo-Ferdinandově univerzitě. Byl žákem Josefa Steplinga (1716-1778), zakladatele klementinské observatoře v roce 1751. Od roku 1781 zastával Strnad funkci ředitele observatoře.

66 Ta se bohužel nedochovala.

67 Falcká (Mannheimská) meteorologická společnost založená roku 1780 se obrátila na třicet učených společností a vynikající vědce Evropy a požádala je o spolupráci při pozorování. Partnerské instituce obdržely zdarma barometr, dva teploměry, vlhkoměr a deklinační jehlu. Srov. Otto SEYdL, Déjiny jezuitského „,musea matematického “ v koleji sv. Klimenta na Starém Městě v Praze, Věstník Královské české společnosti nauk, třída matematicko-přírodovědná, 1951, č. VII. 
předány roku 1781 z Mannheimu do Klementina. Pražská observatoř i další evropské instituce se staly součástí mezinárodní sítě pro pozorování počasí organizované mannheimskou společností, kterou založil kurfiřt Karl Theodor. Barometr byl umístěn ve čtvrtém patře klementinské věže. Měřicí př́stroj je uložen v dřevěné kazetě, kterou tvoří dvě desky spojené závěsy. Barometr je zapuštěný v pravé části kazety a doplňkový teploměr v levé. Barometr má stupnici rozdělenou na pařížské palce (palec $=27,07 \mathrm{~mm}$ ) a číslovanou $25-30$. Ke stupnici př́sluší nonius číslovaný $0-10 \mathrm{k}$ přesnému odečítání tlaku. $\mathrm{K}$ tomu patří redukční rtut'ový teploměr se stupni Réaumura $\left({ }^{\circ} \mathrm{R}\right)-20-0-80$. Podle teploměru se barometrická měření redukovala na teplotu $+10^{\circ}$ R. Jedná se o kvalitní prrístroj, který splňoval podmínky pro přesná měření.

Ostatní tlakoměry pocházejí z 19. století, mezi nimi vynikají výrobky známých firem: J. G. Greiner \& Geissler, Berlin; L. J. Kappeller, Wien; Carlo Grindel, Milano. Další př́istroj je označený nápisem „Profesor Hallaschka“, zřejmě patřil do jeho výbavy. František Ignác Kassián Halaška působil v Praze (1814-1832) na univerzitě jako profesor fyziky. Během svého pražského pobytu prováděl od roku 1817 ve svém bytě na Novém Městě

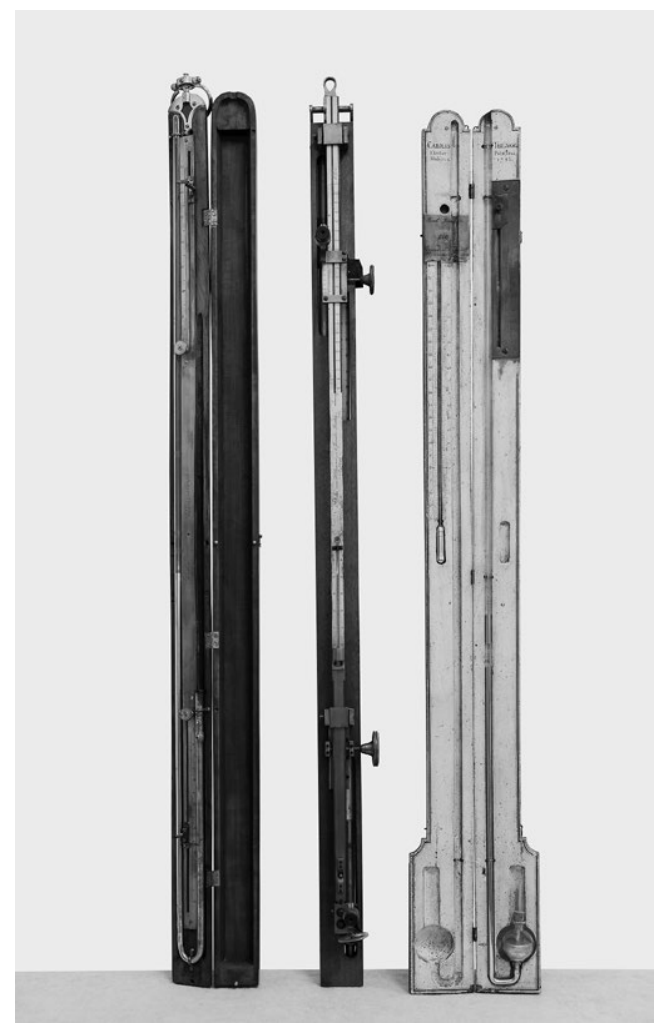

Obr. 21 Barometry: signováno Hallaschka (inv. č. 17130), výška 1000 mm; signováno J. G. Greiner \& Geissler, Berlin (inv. č. 17123), výška 960 mm; signováno Palatinus 1780 (inv. č. 17126), výška $955 \mathrm{~mm}$ (foto Patrik Sláma) 


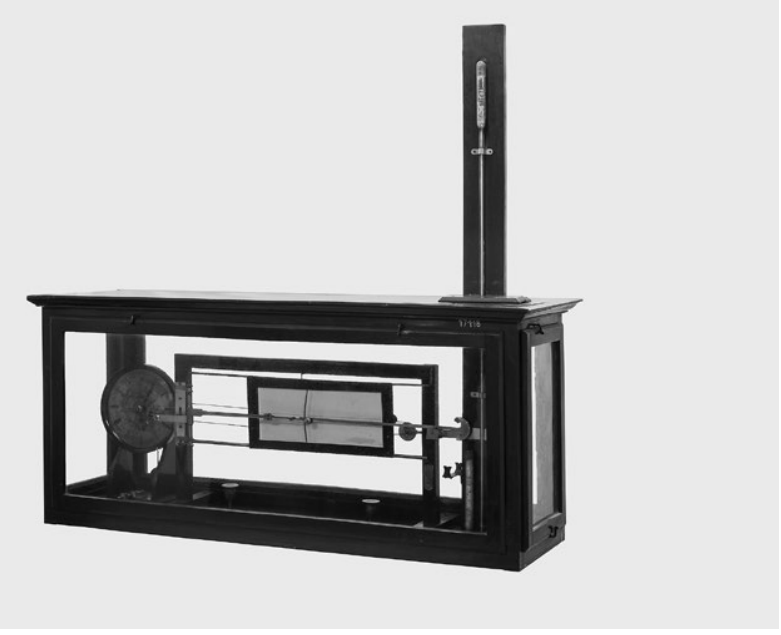

Obr. 22 Barograf (inv. č. 17118) signovaný „Barometer 1844“ a „F. Dressler in Prag“, $470 \times 1060 \times 340 \mathrm{~mm}$ (foto Patrik Sláma)

astronomická, meteorologická a geomagnetická pozorování. Měl k tomu dobře vybavenou astronomickou observatoř. Prováděl nezávislá pozorování, souběžná s měřeními v Klementinu a spolupracoval s Aloisem Martinem Davidem. ${ }^{68}$

Mezi staniční přístroje observatoře patřila i automatická registrační zařízení jako barograf a termograf. Obě zařízení byla konstruována podle návrhu Karla Kreila. ${ }^{69}$ Zapisují časový průběh tlaku, respektive teploty v průběhu delšího časového úseku, většinou jednoho dne. K tomu slouží hodinový stroj, který posunuje pomocí převodu rám se záznamovým listem. Při změně tlaku (teploty) vzduchu se mění výška rtut'ového sloupce a tím i poloha pákového mechanizmu, jehož plovák dosedá na hladinu rtuti. Na opačném konci páky je zapisovací zařízení, které nakreslí tečku každých 5 minut na záznamový papír. Barograf je umístěný v prosklené skř́ni s nápisem „Barometer 1844“, na ciferníku hodin s pérovým natahováním a kyvadlem je nápis „F. Dressler in Prag“. Výhoda tohoto předmětu je zřejmá, přístroj prováděl měření a zaznamenával meteorologické hodnoty sám, bez obsluhy.

Kromě měření teploty a tlaku vzduchu probíhala další důležitá pozorování meteorologických veličin týkající se větru. K tomu sloužil anemometr (z řeckého anemos - vítr), který byl zařizen $\mathrm{k}$ měření rychlosti a směru větru. Energie větru se přenáší na otočné zařizení s miskami. Př́ístroj z Klementina je konstruován jako anemograf k automatickému záznamu obou veličin a sestrojil ho anglický výrobce Adie. ${ }^{70}$ Jeho venkovní část se skládá z masivní litinové základny a stojanu, větrné korouhve a miskového anemometru (Robinsonův kř́ž).

68 Alois Martin David (1757-1836), astronom, kartograf, geodet a tepelský premonstrát byl ředitelem klementinské observatoře v letech 1799-1836.

69 Karel Kreil (1798-1862), odborník na kometární astronomii a zemský magnetizmus, působil v Praze v letech 1838-1851, roku 1845 se stal ředitelem klementinské observatoře.

70 Patrick Adie (1821-1866), zakladatel firmy vyrábějící optické, matematické a vědecké prrístroje. Firma Adie produkovala sortiment v letech 1848-1901 v Londýně. 

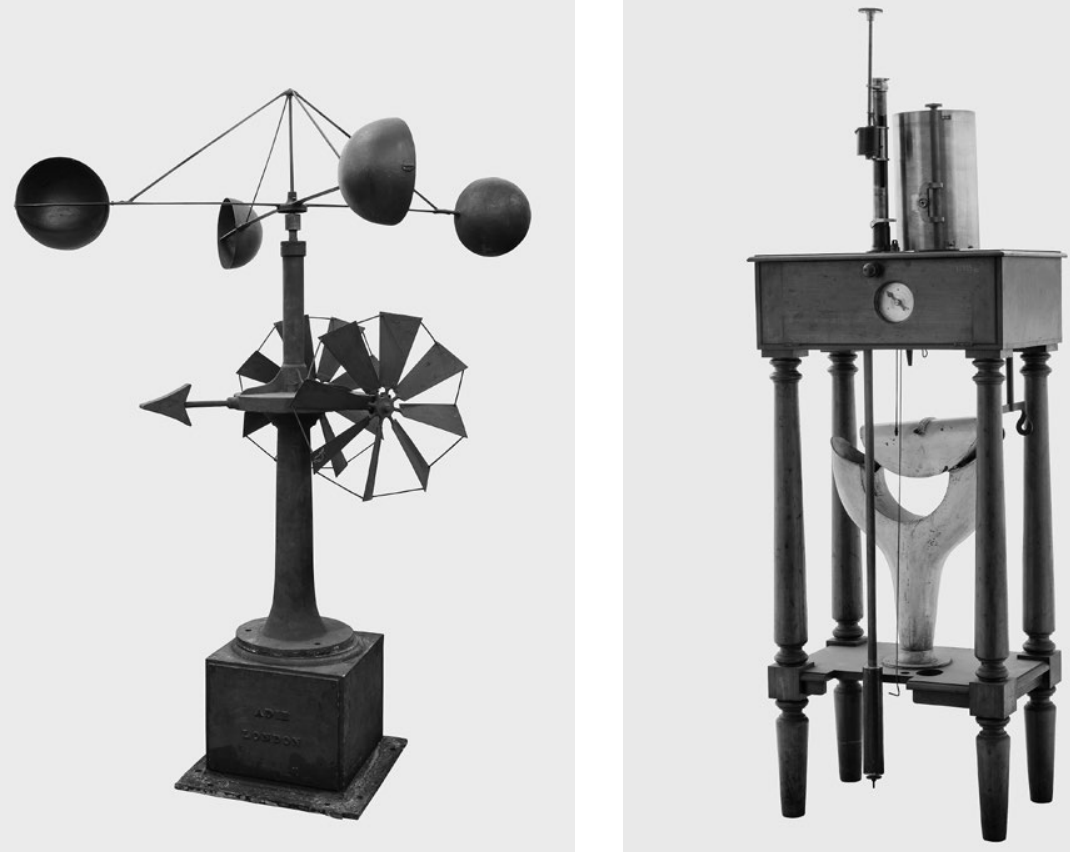

Obr. 23a,b Anemograf (inv. č. 17115) s Robinsonovým křížem (průměr misek 230 mm, rozteč $1440 \mathrm{~mm}$ ), větrnou korouhví a zapisovacím zařízením, Patrick Adie Londýn (foto Patrik Sláma)

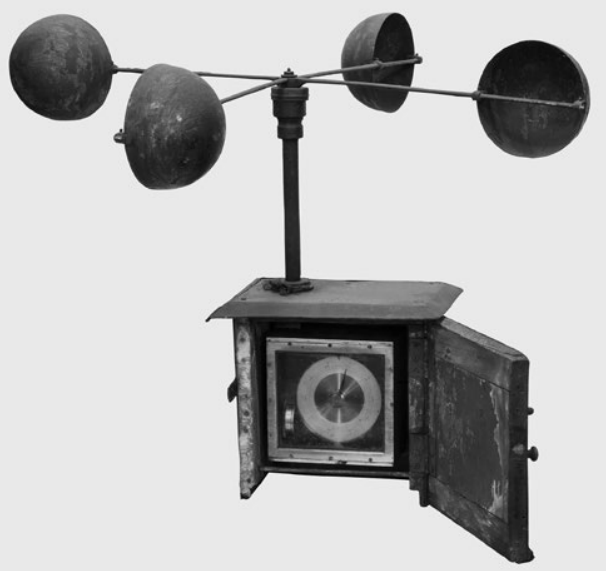

Obr. 24 Anemograf (inv. č. 17121), přenosný přístroj (průměr misek $115 \mathrm{~mm}$, rozteč 540 mm), Kraft Vídeň, druhá polovina 19. století (foto Patrik Sláma) 
Venkovní zařízení bylo umístěno na plošině ve výšce hřebene střechy. Pod ním v podkroví byla uložena záznamová část zařízení, válec s papírem, zapisovač a hodinový stroj. Tato část př́stroje je spojena dvěma vysunovacími tyčemi procházejícími střechou s venkovním zařízením.

\section{Závěr}

V Klementinu byly původně př́stroje a pomůcky uloženy v astronomické věži, meteorologické observatoři a matematickém muzeu. Nejstarší funkční prŕstroje sahají až do začátku 18. století. Muzejní sbírky začaly být shromažd’ovány již dř́ve. Roku 1722 byla dokončena astronomická věž a ve stejném roce bylo založeno Matematické muzeum, které bylo prvním muzeem u nás a patřilo $\mathrm{k}$ nejstarším muzejním sbírkám v Evropě. ${ }^{71}$ „,Museum mathematicum Collegii Clementini“" zahrnovalo glóby, optické, fyzikální, geometrické, astronomické a časoměrné pomůcky. Muzeum obsahovalo také kolekce „nematematické““ povahy z oborů botaniky, zoologie, etnografie a mineralogie, dále automaty, kuriozity a jiné artefakty inspirované sbírkami Rudolfa II. Matematické muzeum mělo své správce, kteří se o soubory starali a rozšiřovali je. Se zrušením jezuitského řádu roku 1773 začala zkáza muzejních sbírek, muzeum bylo zrušeno v roce 1785 . Sbírky měnily své stanoviště v Klementinu a některé předměty byly předány jinam. Největší devastace muzejních kolekcí přišla $v$ osobě ředitele astronomické observatoře Josefa Böhma, který rozprodal v polovině 19. století více jak sto cenných věcí jako bezvýznamné krámy. V důsledku toho byla část světově unikátní sbírky vytržena $\mathrm{z}$ celku, mnoho předmětů se dostalo do zahraničí a další byly nenávratně ztraceny. Další velké úbytky nastaly po roce 1948, kdy byly předány téměř všechny zbývající předměty do pražských muzeí. V Klementinu zůstaly pouze hodiny (troje Kleinovy a jedny Trauttmansdorffské) a soubor 14 glóbů v barokní knihovně.

Z tohoto pohledu musíme být rádi, že se v Národním technickém muzeu (a také v Národním muzeu) podařilo zachránit některé památky z velmi slavné historie Matematického muzea pro další generace. Stejně tak jsou uchovány jedinečné prŕstroje z pravidelných meteorologických měření v Klementinu, která pokračují dodnes. Kolekce dochovaných př́istrojů tvoří základ sbírek NTM v oborech astronomie, fyziky a dalších. Exaktní vědy hrály vždy důležitou roli ve vědeckém pokroku ve světě i u nás a bez existence př́istrojové techniky by nemohla být konána důležitá měření a pozorování. NTM kromě uchování těchto památek věnuje patřičnou pozornost jejich prezentování. Významná část předmětů z Klementina je součástí trvalých expozic i krátkodobých výstav NTM i našich partnerů. O významu tohoto př́strojového a kulturního dědictví hovoří i skutečnost, že roku 2016 byly dva renesanční př́stroje pocházející z Klementina (sextant Josta Bürgiho a sextant Erasma Habermela) prohlášeny za národní kulturní památku.

71 Jeho vzorem bylo ř́mské Collegii Romani Societatis Jesu Museum založené roku 1650, British Museum v Londýně pochází až z roku 1753. 


\section{Bibliografická poznámka}

BRAHE Tycho, Astronomiae instauratae mechanica, Wansbek 1598

Daumas Maurice, Les Instruments Scientifiques aux XII et XVII siècles, Paris 1953

Hevelius Johannes, Machina coelestis, pars I, Organographiam, sive instrumentorum astronomicorum omnium, Danzig 1673

Hevelius Johannes, Machina coelestis, pars II, Rerum Uranicarum Observationes..., Danzig 1679

HoRSKÝ Zdeněk - ŠKopOVÁ Otilie, Astronomy gnomonics: a catalogue of instruments of the 15th to the 19th centuries in the collections of the National Technical Museum Prague, Praha 1968

HoRskÝ Zdeněk, Bürgiho sextant ve sbírkách Národního technického muzea v Praze, Sborník Národního technického muzea v Praze, 5, 1968, s. 279-300

HoRský Zdeněk, Sextant Tychona Brahe ve sbírkách Národního technického muzea v Praze, Zprávy čs. společnosti pro dějiny věd a techniky, 2, 1965, s. 46-49

KRŠKa Karel - Š Amaj Ferdinand, Dějiny meteorologie v českých zemích a na Slovensku, Praha 2001

KYNČL Radko, Hodiny a hodinky, Praha 2001

KYNČL Radko, Katalog expozice Měrení času, NTM Praha 2015

Michal Stanislav, Hodiny: od gnómonu k atomovým hodinám, Praha 1980

Michal Stanislav - Laboutková Irena, Katalog expozice měření času Národního technického muzea v Praze, Praha 1997

OulíkovÁ Petra, Klementinum: průvodce, Praha 2006

PejMl Karel, 200 let meteorologické observatoře v pražském Klementinu, Praha 1975

Seydl Otto, Z nejstaršich dějin Pražské hvězdárny: k sedmdesátinám prof. dr. Fr. Nušla, Praha 1938

SEYdL Otto, Dějiny jezuitského „,musea matematického“ v koleji sv. Klimenta na Starém Městě v Praze, in: Věstník Královské české společnosti nauk, tř. matematicko-přírodovědná, 1951, č. VII

Seydu Otto, Mannheimská společnost meteorologická (1780-1799), Praha 1954, dostupné online: http://www.cmes.cz/en/node/253

Š́ma Zdislav, Astronomie a Klementinum, Praha 2006

Š́ma Zdislav, Prague Sextants of Tycho Brahe, Annals of Science 50/5, 1993, s. 445-453

Švejda Antonín, Kepler a Praha, Praha 2004

ŠveJdA Antonín, Katalog expozice Astronomie, NTM Praha 2014

L'E TuRNER Gerard, Scientific instruments 1500-1900, London 1998

WeInex Ladislaus, Die Tychonischen Instrumente auf der Prager Sternwarte, Praha 1901

WeINEK Ladislaus, Ein alter bemerkenswerter Quadrant der Prager Sternwarte, in: Astronomische Beobachtungen an der K. K. Sternwarte zu Prag in den Jahren 1905-1909, Praha 1912

ZINNER Ernst, Deutsche und niederländische astronomische Instrumente des 11.-18. Jahrhunderts, München 1956 


\title{
ANTONÍN ŠVEJDA
}

\section{Instrumente und Hilfsmittel aus dem Klementinum in der Sammlung des Nationalen Technischen Museums}

\section{ZUSAMMENFASSUNG}

Im Nationalen Technischen Museum (NTM) befindet sich ein Ensemble bedeutender Instrumente und Hilfsmittel, die aus dem Prager Klementinum stammen. Ins Museum gelangten sie Anfang der 1950er Jahre. Insgesamt handelt es sich um 82 Objekte unterschiedlichen Charakters, die in den Sammlungen Astronomie (40 Objekte), Geodäsie (13), Physik (19) und Zeitmessung (10) aufbewahrt werden. Die damalige staatliche Sternwarte im Klementinum schenkte dem Museum ein hervorragendes Ensemble astronomischer Geräte: Sonnenuhren, Fernrohre, Armilarsphären, Tellurien, Globen und Demonstrationshilfsmittel. Die Anschaffung wird von der Sammlung großer astrometrischer Apparaturen vom 16. bis 19. Jahrhundert dominiert, an deren Spitze zwei Sextanten (J. Bürgi, E. Habermel) aus der Zeit um 1600 stehen. Andere Geräte in dieser Reihe sind Quadranten und Kreisinstrumente (Altazimut, Passageinstrument). Kein anderes Museum verfügt über eine solche außerordentliche Astrometrie-Sammlung. Die Globen-Sammlung enthält Modelle von Mond und Mars; unter den Demonstrationsobjekten befinden sich Unikate, wie beispielsweise ein Uranoskop und ein Instrument mit vier Globen. Ein weiterer Teil der Anschaffung besteht aus physikalischen Instrumenten zur Erforschung des Wetters, wie sie im meteorologischen Observatorium des Klementinums verwendet wurden: Windstärkenmesser (Anämometer), Thermographen, Barometer, Niederschlagsmesser und andere Instrumente. In der Uhren-Sammlung befinden sich bedeutende Konstruktionen von astronomischen Regulatoren und Bodenstanduhren, die bei der astronomischen Beobachtung Verwendung fanden. Das Interessante der Anschaffung besteht in Objekten, die eine Persönlichkeit betreffen: den Jesuiten, Astronomen und Konstrukteur von Instrumenten Johann Klein. In dem Ensemble der Objekte befindet sich ein von Klein hergestellter Quadrant sowie sein einziges erhaltenes Porträt.

Die bedeutendsten astronomischen Geräte sind jetzt in der Dauerausstellung Astronomie zu sehen, Uhren und Uhrwerke in der Ausstellung Zeitmessung. Viele andere Objekte werden bei gelegentlichen Ausstellungen des NTM, der Nationalbibliothek und weiterer Partnerinstitutionen gezeigt. Von der Bedeutung dieses kulturellen Erbes zeugt auch der Umstand, dass 2016 zwei aus dem Klementinum stammende Renaissancegeräte (der Sextant von Jost Bürgi und der von Erasmus Habermel) zum nationalen Kulturdenkmal erklärt wurden.

Deutsche Übersetzung Wolf B. Oerter

\author{
Antonín Švejda \\ Národní technické muzeum, Praha \\ antonin.svejda@ntm.cz
}

